\title{
Deep-sea Ampharetidae (Polychaeta) from Capbreton Canyon (north-east Atlantic) with the description of a new species
}

\author{
Florencio Aguirrezabalaga (a1)(a2), Julio Parapar (a3) \\ (a1) Donostiako Irakasleen U.E., Euskal Herriko Unibertsitatea, UPV-EHU, Oñati plaza 3, 20018 \\ Donostia, Spain \\ (a2) S.C. INSUB E.K., Zemoria 12, 3223 P.K., 20013 Donostia, Spain \\ (a3) Departamento de Bioloxía Animal, Bioloxía Vegetal e Ecología, Universidade da Coruña, Rúa da Fraga \\ 10, 15008 A Coruña, Spain
}

This article has been published in a revised form in Journal of the Marine Biological Association of the United Kingdom [ http://dx.doi.org/10.1017/S0025315413001422 ]. This version is free to view and download for private research and study only. Not for re-distribution, re-sale or use in derivative works. (c) copyright holder.

\section{How to cite}

Aguirrezabalaga F., Parapar J. (2014) Deep-sea Ampharetidae (Polychaeta) from Capbreton Canyon (north-east Atlantic) with the description of a new species. Journal of the Marine Biological Association of the United Kingdom 94(5), 947-967

\begin{abstract}
During the Capbreton cruises (1987-1990), samples of bathyal benthic macrofauna were taken at 37 stations situated along the continental slope (480-1113 m depth) of the Capbreton Canyon (Bay of Biscay, north-east Atlantic). Ten species of polychaetes belonging to six genera (Melinna, Eclysippe, Amphicteis, Anobothrus, Glyphanostomum and Tanseimaruana) of the family Ampharetidae Malmgren, 1866 were collected at 13 of these stations. Most of these species are reported for the first time in the area. Amphicteis aff. wesenbergae is reported for the first time after its recent description and a new species belonging to the genus Glyphanostomum is here described. Moreover, the finding of Melinna monoceroidesrepresents the northernmost record of the species; Tanseimaruana vestis is recorded for the second time from the East Atlantic after its recent finding in Icelandic waters; Anobothrus aff. gracilis is reported for the second time from the Iberian Peninsula, representing, the southernmost record of the species in the Atlantic Ocean. The potential identification of two fragments of an Ampharetinae indet as Anobothrus laubieri, a deep water Arctic species, is discussed.
\end{abstract}

Keywords: Polychaeta, Ampharetidae, Glyphanostomum, Tanseimaruana, deep-sea, Bay of Biscay, north-east Atlantic, new records, new species 


\section{INTRODUCTION}

The Ampharetidae (Annelida: Polychaeta) are marine benthic, deposit feeding worms, which frequently burrow through the substrate or build sandy or muddy tubes in which they live, from shallow waters to the deep sea. The systematics of the family is still far from being well defined; the number of valid genera is different depending on the authority (e.g. 21 according to Jirkov (2011) or 73 and 71 according to Salazar \& Hutchings (2012) and Reuscher et al. (2009), respectively). Since papers by Hartley (1985) and Holthe (1986a, b), knowledge of this family has had significant contributions, from Mackie \& Pleijel (1995), Jirkov (2001, 2008) and Parapar et al. (2011, 2012) for European waters, and from Hilbig (2000), Holthe (2000), Jirkov (2008), Schüller (2008), Reuscher et al. (2009) and Imajima et al. $(2012,2013)$ for other oceans.

The contribution of the study of deep-sea benthic fauna to the knowledge of the taxonomy and ecology of the marine environment is currently increasing. In recent years, a number of studies have been conducted on the Atlantic coast of the Iberian Peninsula focused on deep-sea invertebrates, which are discovering new species to science and producing new reports of polychaetes (e.g. Moreira \& Parapar, 2007; Parapar \& Moreira, 2009; Lucas et al., 2012).

The Capbreton Canyon is a submarine valley located on the continental shelf and slope of the Bay of Biscay. The latter is divided in two zones, the northern Aquitanian continental shelf and the southern Cantabrian shelf. From 1987 to 1990, four oceanographic cruises were conducted on board the RV 'Côte d'Aquitaine' as part of the Franco-Spanish Capbreton research project led by Dr J.C. Sorbe from the Laboratoire d'Océanographie Biologique (LOB) of the Centre National de la Recherche Scientifique (CNRS). During these cruises, samples of benthic macrofauna were taken at 37 stations situated along the continental slope from 480 to 1113 m depth, on both sides of the Capbreton Canyon.

Some of the results obtained from the study of the polychaetes collected by the Capbreton programme have already been published in Rallo et al. (1993), San Martín et al. (1996), Aguirrezabalaga et al. (1999, 2001, 2002), Núñez et al. (2000), Aguirrezabalaga \& Carrera-Parra (2006), Aguirrezabalaga \& Ceberio (2003, 2005a, b, 2006) and Aguirrezabalaga \& Gil (2009). Rallo et al. (1993) reported five species of Ampharetidae from depths between 100 and $450 \mathrm{~m}$ : Melinna palmataGrube, 1870, Amphicteis gunneri (Sars, 1835), Ampharete sp., Anobothrus gracilis (Malmgren, 1866) (as Ampharete) andAuchenoplax crinita Ehlers, 1887.

This paper includes ten ampharetid species belonging to six genera, of which one is a new species to the genus Glyphanostomun Levinsen, 1884.

\section{MATERIALS AND METHODS}

The specimens, belonging to the family Ampharetidae Malmgren, 1866, were collected in the Capbreton Canyon at 13 stations, mostly located in the Cantabrian shelf, covering a depth range from 495 to $1113 \mathrm{~m}$ (Figure 1 and Table 1). Three different types of gear were used: a Sanders-Hessler epibenthic dredge (DI), a Flusha box-corer (KF) and a Marinovitch trawl (CM). Samples obtained with DI and KF were sieved through a $0.5 \mathrm{~mm}$ mesh size; samples from CM were not sieved. 
Specimens were fixed in $10 \%$ formalin buffered with borax, and preserved in $70 \%$ ethanol. Material examined, including the type series of the new species, was deposited in the collections of the Museo Nacional de Ciencias Naturales, Madrid (MNCN); Sociedad Cultural de Investigación Submarina, Donostia (INSUB) and personal collection of J. Parapar, Departamento de Bioloxía Animal, Universidade da Coruña (UDC).

Specimens of all species were stained with methyl green (MG) and staining pattern of each species were documented following the methodology proposed by Schüller \& Hutchings (2010).

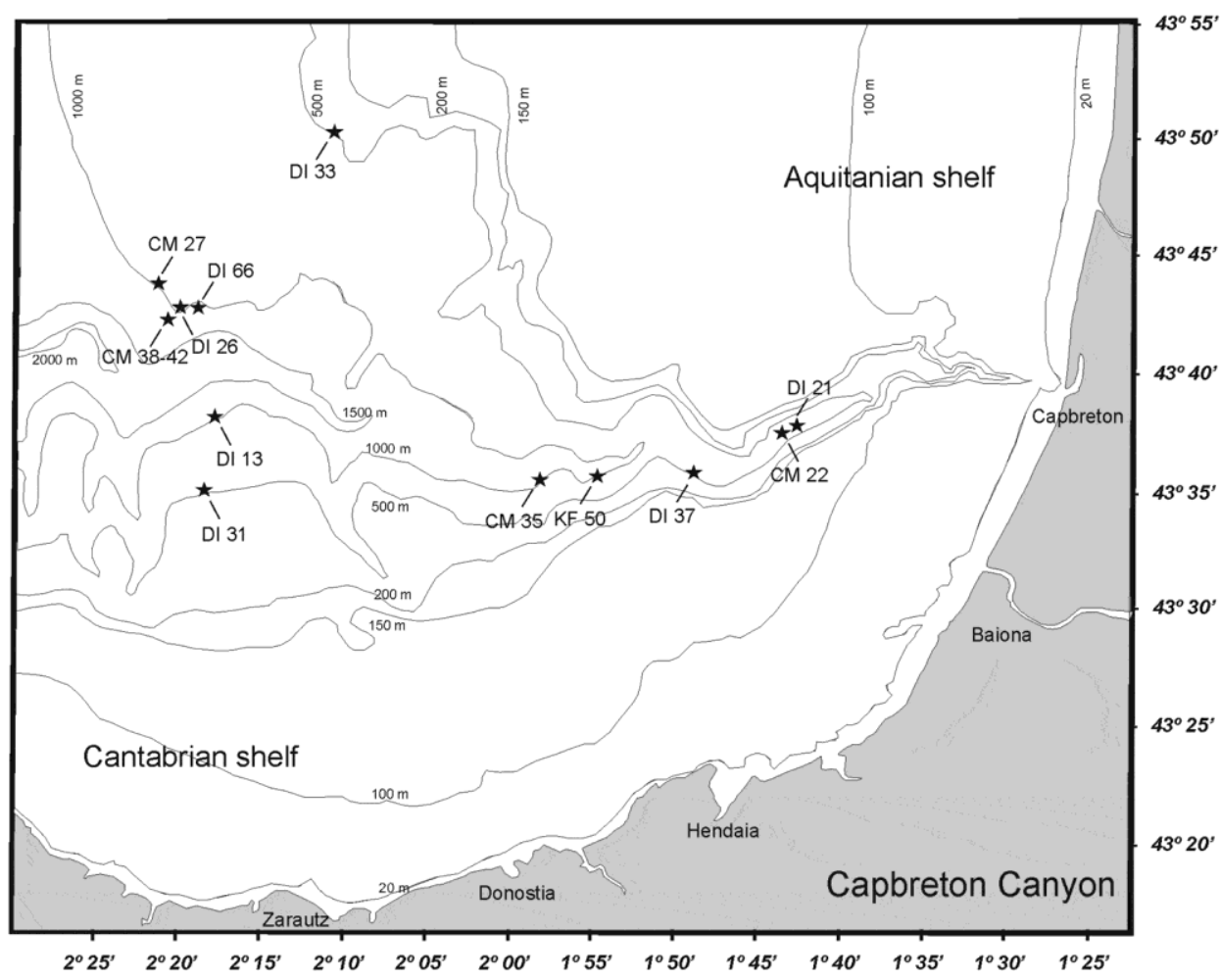

Fig. 1. Capbreton Canyon (Bay of Biscay) showing sampling stations where species of Ampharetidae were found.

Table 1. Main characteristics of the sampling stations in the Capbreton Canyon, with ampharetid specimens. Date format is day, month, year. Abbreviations: DI, Sanders-Hessler dredge; CM, Marinovitch trawl; KF, Flusha box-corer.

\begin{tabular}{|c|c|c|c|c|c|}
\hline Station & Gear & Date & $\begin{array}{l}\text { Position at the beginning } \\
\text { of the tow on the sea-floor }\end{array}$ & Depth (m) & Species \\
\hline 13 & DI & $06 / 07 / 1988$ & $43^{\circ} 38.36^{\prime} \mathrm{N}, 02^{\circ} 18.03^{\prime} \mathrm{W}$ & 1040 & Amphicteis indet.; G. moreirai spec. nov. \\
\hline 21 & DI & $07 / 07 / 1988$ & $43^{\circ} 37.72^{\prime} \mathrm{N}, 01^{\circ} 41.83^{\prime} \mathrm{W}$ & 580 & A. midas \\
\hline 22 & $\mathrm{CM}$ & $07 / 07 / 1988$ & $43^{\circ} 37.79^{\prime} \mathrm{N}, 01^{\circ} 42.91^{\prime} \mathrm{W}$ & 624 & $\begin{array}{l}\text { M. monoceroides; } A . \text { midas; } \\
\text { A. aff. wesenbergae; } A \text {. aff. gracilis }\end{array}$ \\
\hline 26 & DI & $08 / 07 / 1988$ & $43^{\circ} 42.89^{\prime} \mathrm{N}, 02{ }^{\circ} 18.71^{\prime} \mathrm{W}$ & 984 & M.cristata; T. vestis; G. moreirai spec. nov. \\
\hline 27 & $\mathrm{CM}$ & o8/o7/1988 & $43^{\circ} 43.19^{\prime} \mathrm{N}, 02^{\circ} 20.13^{\prime} \mathrm{W}$ & 954 & M. cristata \\
\hline 31 & DI & $10 / 07 / 1988$ & $43^{\circ} 35.87^{\prime} \mathrm{N}, 02^{\circ} 17.43^{\prime} \mathrm{W}$ & 505 & E. vanelli \\
\hline 33 & DI & $10 / 07 / 1988$ & $43^{\circ} 50.32^{\prime} \mathrm{N}, 02^{\circ} 10.90^{\prime} \mathrm{W}$ & 495 & E. vanelli \\
\hline 35 & $\mathrm{CM}$ & $11 / 07 / 1988$ & $43^{\circ} 35,42^{\prime} \mathrm{N}, 01^{\circ} 57,00^{\prime} \mathrm{W}$ & 994 & M. cristata \\
\hline 37 & DI & $11 / 07 / 1988$ & $43^{\circ} 36.25^{\prime} \mathrm{N}, 01^{\circ} 48.24^{\prime} \mathrm{W}$ & 508 & A. midas; G. moreirai spec. nov. \\
\hline 38 & KF & $12 / 09 / 1989$ & $43^{\circ} 41.90^{\prime} \mathrm{N}, 02^{\circ} 18.54^{\prime} \mathrm{W}$ & 1003 & M. cristata \\
\hline 42 & $\mathrm{KF}$ & $12 / 09 / 1989$ & $43^{\circ} 41.95^{\prime} \mathrm{N}, 02^{\circ} 18.41^{\prime} \mathrm{W}$ & 1017 & G. moreirai spec. nov. \\
\hline 50 & KF & $14 / 09 / 1989$ & $43^{\circ} 35.35^{\prime} \mathrm{N}, 01^{\circ} 55.15^{\prime} \mathrm{W}$ & 1000 & A. midas; Ampharetinae indet. \\
\hline 66 & DI & $16 / 09 / 1989$ & $43^{\circ} 43.23^{\prime} \mathrm{N}, 02^{\circ} 17.51^{\prime} \mathrm{W}$ & 1026 & G. moreirai spec. nov. \\
\hline
\end{tabular}


Illustrations were made using a camera lucida attached to a light microscope. Specimens used for examination with a scanning electron microscopy (SEM) were prepared by critical point drying, covered with gold in a BAL-TEC SCD-004 evaporator, and examined and photographed under a JEOL JSM-6400 scanning electron microscope at the Servicios de Apoio á Investigación (SAI), University of A CoruñaUDC, Spain.

For comparison purposes, type material of Amphicteis wesenbergae Parapar et al., 2011 and other specimens from selected species were studied by authors during several research stays in the Sandgerdi Marine Centre, Iceland (IMNH) and the Zoological Museum, University of Copenhagen, Denmark (ZMUC). Species descriptions and terminology follow Hartley (1985), Holthe (1986a, b), Jirkov (2008), Reuscher et al. (2009), Parapar et al. (2011, 2012) and Imajima et al. (2013).

The term 'intermediate uncinigers' proposed by Imajima et al. (2012) was used for those segments without notopodia and notochaetae but with neuropodia formed as 'tori' (thoracic neuropodia) and not as 'pinnules' (abdominal neuropodia). Accordingly, these segments are included in the following descriptions as an 'intermediate region' between thorax and abdomen. Consequently, the abdomen may have a lower number of segments compared to traditional descriptions, because only those segments that bear neuropodial pinnules are considered abdominal. Schematic drawings of branchiae arrangement proposed by Reuscher et al. (2009) are included for several species of Ampharetinae, and nomenclatural recommendations on some body structures (e.g. prostomium, uncinigers, uncini) proposed by Jirkov $(2008,2011)$ and Imajima et al. $(2012,2013)$ are used in species descriptions.

Abbreviations: $\mathrm{CH}$ for chaetiger, $\mathrm{TU}$ for thoracic unciniger and $\mathrm{SG}$ for segment.

\section{RESULTS AND DISCUSSION}

\section{Species richness and abundance}

A total of 131 ampharetid specimens of polychaetes belonging to six genera and ten species were collected. Most specimens belong to the genera Amphicteis Grube, 1850 (3 spp.; 63 specimens; 48.1\% total abundance) and EclysippeEliason, 1955 (1 sp.; $39 \quad$ specimens; 29.8\%), while Tanseimaruana Imajima, Reuscher \& Fiege, $2013\left(\begin{array}{lllll}1 & \text { sp.; } & 10 & \text { specimens; }\end{array}\right.$ 7.6\%), Glyphanostomum Levinsen, 1884 (1 sp.; 8 specimens; 6.1\%), Melinna Malmgren, 1866 (2 spp.; 8 specimens; 6.1\%), Ampharetinae (1 sp., 1 specimen; 0.8\%) and Anobothrus Levinsen, 1884 (2 spp.; 2 specimens; $1.5 \%$ ) are of minor quantitative relevance (Figure 2A; Table 1). No specimens of Ampharete were found. These results are in accordance with those found by Rallo et al. (1993) in the same area, but at shallower depths $(100-450 \mathrm{~m})$. These authors also reportAmphicteis gunneri and Anobothrus gracilis (as Ampharete) (both species were probably present in our study, but their identification is not fully confirmed yet), an unidentified Ampharete species, and two species not found in our cruises:Melinna palmata and Auchenoplax crinita. Melinna palmata is a common shallowwater species in the Iberian Peninsula (Ariño, 1987; Parapar et al., 1996) and A. crinita was also reported by Parapar \& Moreira (2009) at similar shelf depths $(200-400 \mathrm{~m})$ from the Galician littoral (north-west Atlantic coast of Spain). 
According to depth, samples could be sorted in two groups (Figure 2B):

- Group 1, upper slope stations (495-624 m depth): DI21, DI31, DI33, DI37 and CM22.

- Group 2, deep slope stations (954-1040 m depth): DI13, DI26, DI66, CM27, CM35, KF38, KF42 and KF50.

Ampharetidae species appear to cluster in these two bathymetric groups, with $M$. monoceroides, $A$. aff. wesenbergae, $E$. vanelli and $A$. aff. gracilis being characteristic for Group 1, and $M$. cristata, Amphicteis indet., Ampharetinae indet. and T. vestis being characteristic for Group 2. Amphicteis midas and G. moreirai sp. nov. appear to be present throughout the entire slope.
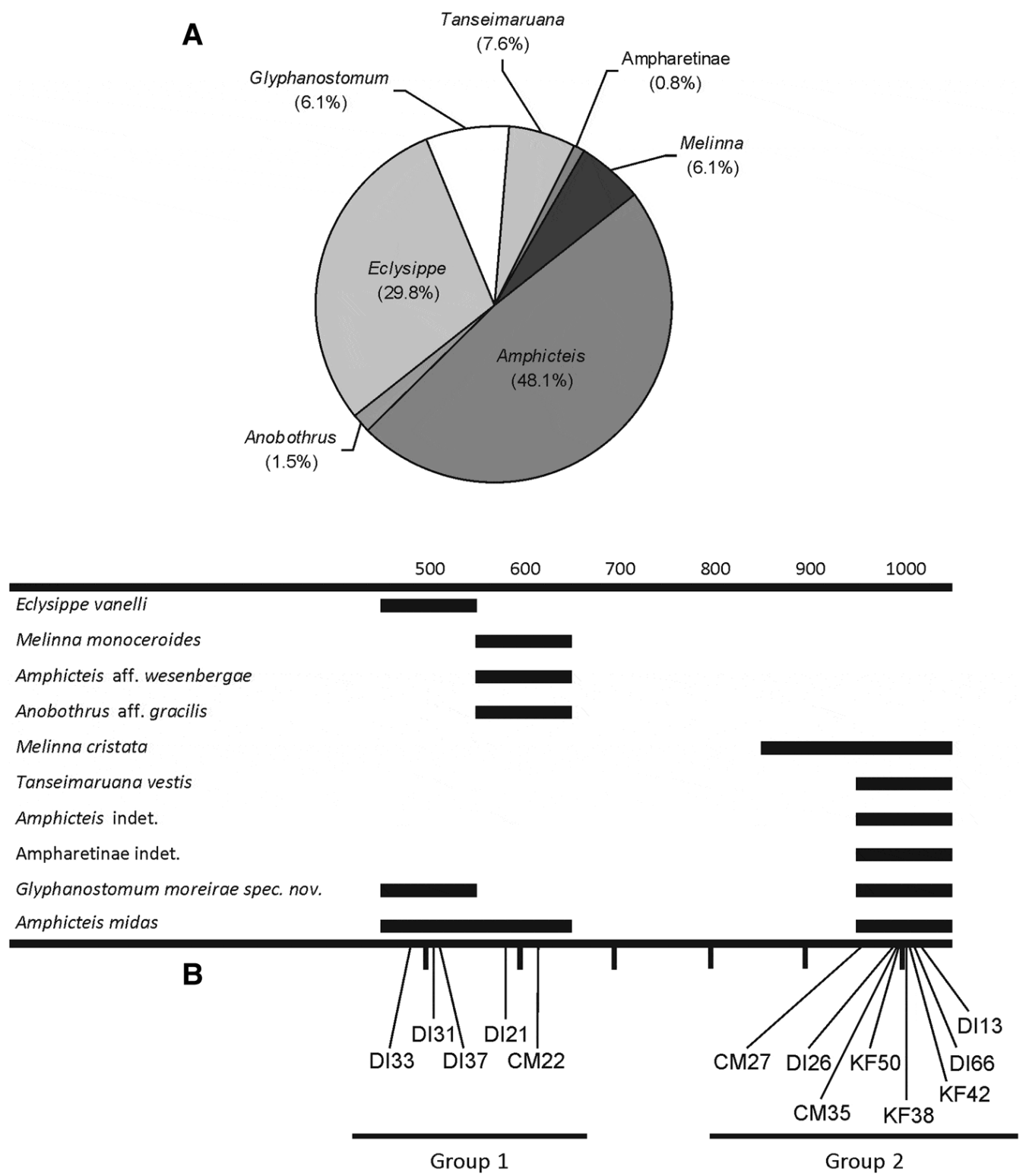

Fig. 2. (A) Relative abundance of each ampharetid genus in the Capbreton Canyon; (B) depth distribution ranges of each ampharetid species and position related to depth of each sample (bottom). 


\section{SYSTEMATICS}

Family AMPHARETIDAE Malmgren, 1866

Subfamily MELINNINAE Malmgren, 1866

We follow Salazar-Vallejo \& Hutchings (2012) who propose Malmgren (1866) instead of Chamberlin (1919) as the author of this subfamily.

\section{Genus ME L I N A Malmgren, 1866}

Melinna cristata (Sars, 1851)

(Figure 3)

Sabellides cristata Sars 1851: 205-206, pl. 2, figs 1-7.

Melinna cristata: Fauvel, 1927: 237-239, fig. 83 i-n; Holthe, 1986a: 81-83, fig. 34, map 33; Mackie \& Pleijel, 1995: 104-111, fig. 1-3, tab. 1; Hartmann-Schröder, 1996: 503.

MATERIAL EXAMINED

MNCN 16.01/15230 (DI26, 1 specimen); POL425 (KF38, 1); POL426 (CM27, 1) and MNCN 16.01/15231 $(\mathrm{CM} 35,3)$.

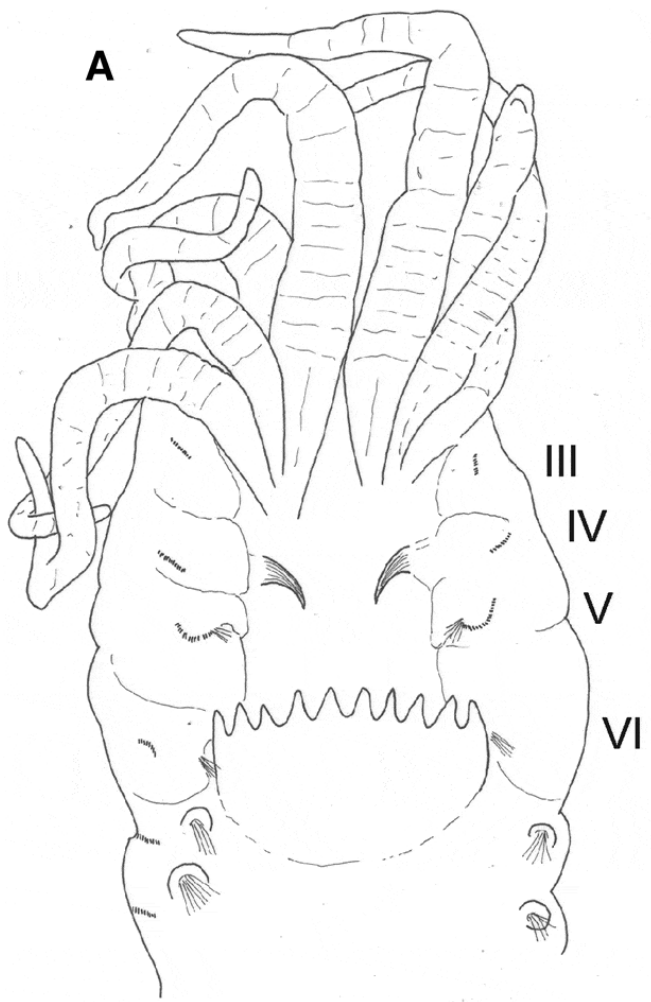

B

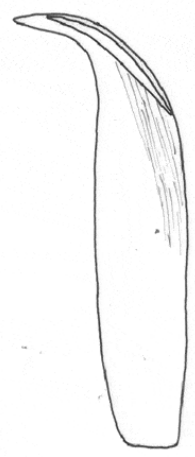

$A=2.73 \mathrm{~mm}$

$\mathrm{B}=794 \mu \mathrm{m}$

C, $D=79 \mu \mathrm{m}$
C
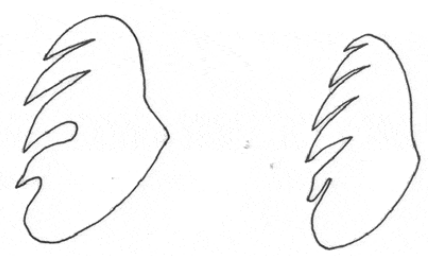

D

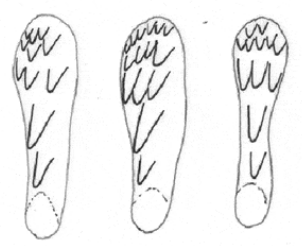

Fig. 3. Melinna cristata: (A) anterior end, dorsal view; (B) postbranchial hook; (C) thoracic uncini, lateral view; (D) abdominal uncini, frontal view. Segments indicated by Roman numerals. 


\section{OCCURRENCE}

Capbreton Canyon (Bay of Biscay), 954-1113 m depth.

\section{DESCRIPTION}

Largest specimen incomplete, $33.5 \mathrm{~mm}$ long (without branchiae), $2.75 \mathrm{~mm}$ wide for 46 chaetigers. Body long, maximum width in postbranchial region, tapering posteriorly. Eighteen thoracic chaetigers and 40 abdominal chaetigers in one complete specimen. Prostomium wider than long, U-shaped, without eyes or glandular ridges. SGI and SGIl achaetous, dorsally covered by branchiae, ventrally forming lower margin of mouth. SGIII-V with characteristic longitudinal dorsolateral ridges. Ventral anterior margin of SGIII crenulated. Two groups of four branchiae in dorsal region of SGIII (CH1) (Figure 3A). Three dorsalmost branchiae of each group basally connected by a membrane and forming an oblique row; fourth branchiae located in front of the middle one of the three. A pair of big postbranchial hooks situated on dorsum of SGIV $(\mathrm{CH} 2)$; hooks with narrow base and gently curved tip, having internal canal (Figure 3B). Dorsum of SGVI (CH4) covered by membranous fold forming anteriorly open pocket. Anterior margin of fold serrated, with 10-12 triangular, sharp points (Figure 3A). SGIII-VI with fine acicular neurochaetae. Starting in SGVII (CH5), fourteen thoracic uncinigers with neuropodia provided with uncini arranged in a single vertical row; last two uncinigers with neuropodia of abdominal type (pinnules). Thoracic uncini with a single vertical row of 3-4 teeth above rostral tooth (Figure $3 \mathrm{C}$ ). From SGV (CH3), 16 thoracic segments with notopodial limbate capillary chaetae; those of $\mathrm{CH} 3$ very small. No intermediate segments. Abdomen with uncinigers provided with pinnules; rudimentary notopodia absent. Abdominal uncini with one tooth and two horizontal rows of 3 and 5 teeth each above rostral tooth, in frontal view (Figure 3D). Pygidium without anal cirri.

\section{MG STAINING PATTERN}

Anterior dorsal region from prostomium to $\mathrm{CH} 6$ heavily stained. Branchiae gently stained. Membranous fold not stained, except in basal part (dorsum of $\mathrm{CH} 5$ and $\mathrm{CH} 6$ ). From $\mathrm{CH} 7$ to $\mathrm{CH} 16$ only lateral parts of segments (parapodia) stained. From $\mathrm{CH} 17$ to end of the body dorsal part not stained. Ventral region from anterior end to $\mathrm{CH} 16$ heavily stained; $\mathrm{CH} 17$ gently stained, $\mathrm{CH} 18$ and whole abdominal region not stained.

\section{REMARKS}

The study of our specimens corroborates the observation of Jirkov (2011) that in the genus Melinna the last two thoracic uncinigers have neuropodia of abdominal type (pinnules instead of tori). These two chaetigers may be also some kind of 'intermediate segments' (see above in Materials and Methods), but not strictly in the sense of Imajima et al. (2012).

\section{DISTRIBUTION}

Portugal, Bay of Biscay, English Channel, south-west of British Isles (Holthe, 1986a). 
Melinna monoceroides Fauvel, 1936

(Figure 4)

Melinna monoceroides: Fauvel, 1936: 93-95, fig. 12; Day, 1967: 687, fig. 35.1.a-b.

MATERIAL EXAMINED

MNCN 16.01/15232 (CM22, 2 specimens).

OCCURRENCE

Capbreton Canyon (Bay of Biscay), 624-652 m depth.

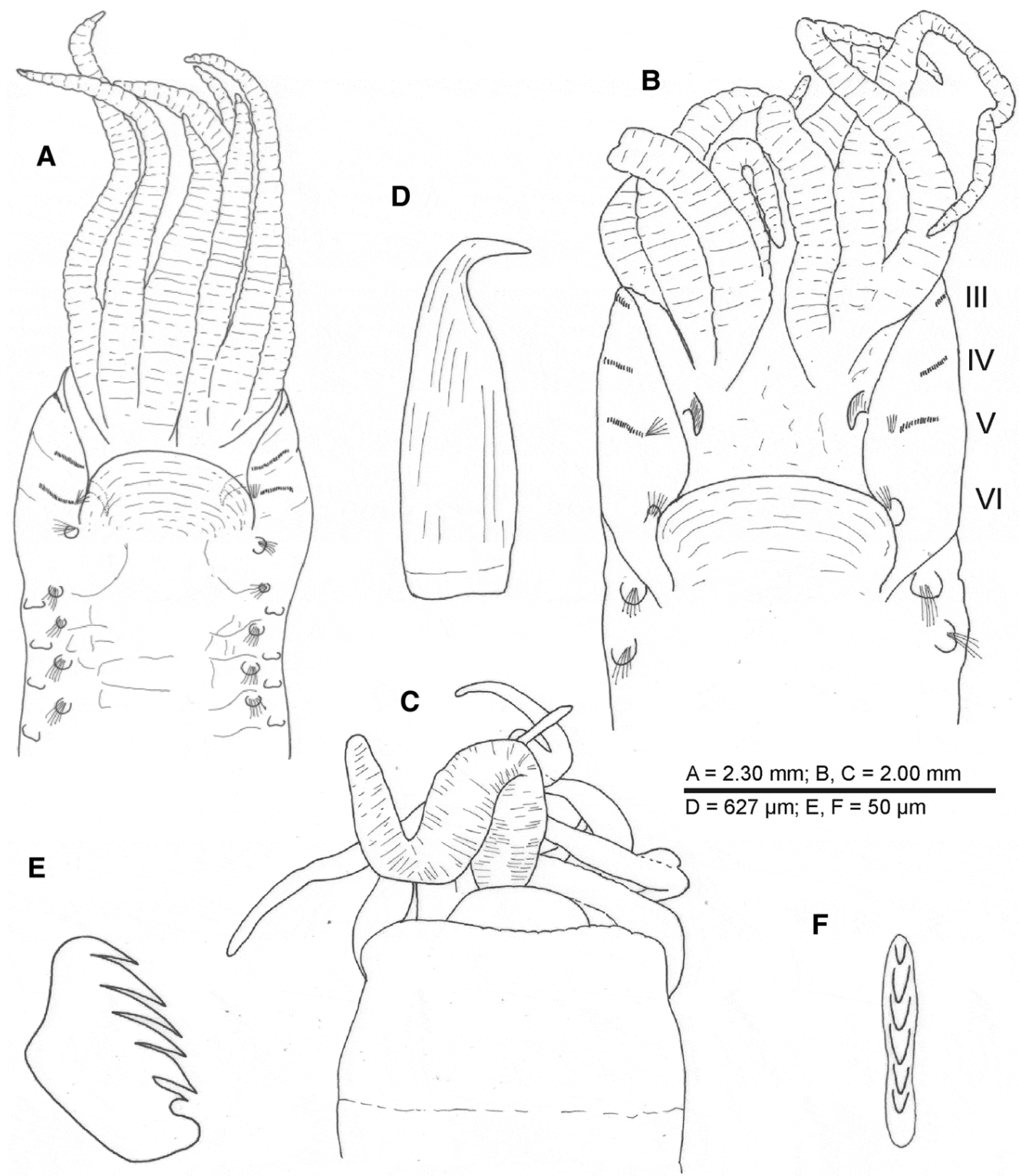

Fig. 4. Melinna monoceroides: (A,B) anterior end, dorsal view; (C) anterior end, ventral view; (D) postbranchial hook; (E) thoracic uncinus, lateral view; $(F)$ abdominal uncinus, frontal view. Segments indicated by Roman numerals. 


\section{DESCRIPTION}

Both specimens incomplete. Largest specimen $35.75 \mathrm{~mm}$ long (without branchiae), $2.1 \mathrm{~mm}$ wide for 48 chaetigers. Body long, maximum width in postbranchial region, tapering posteriorly. Eighteen thoracic chaetigers. Prostomium U-shaped, without eyes or glandular ridges. SGI and SGIl achaetous, dorsally covered by branchiae and ventrally forming a lower margin of mouth. SGIII-V with characteristic longitudinal, dorsolateral ridges (Figure 4A, B). Two groups of four branchiae in dorsal region of SGIII $(\mathrm{CH} 1)$. Three dorsalmost branchiae of each group basally connected by a membrane. Fourth branchiae in front of the middle one of the three. A single greatly enlarged tentacle arising from upper lip (Figure 4C). A pair of big postbranchial hooks situated on dorsum of SGIV (CH2). Hooks with broad base, abruptly tapering, tip bent at right angle, lacking internal canal (Figure 4D). Dorsum of SGVI (CH4) covered by membranous fold forming anteriorly open pocket. Anterior margin smooth, complete, rounded (Figure 4A, B). SGIII-V with fine acicular neurochaetae. SGVI without neurochaetae. Starting in SGVII (CH5), 14 thoracic uncinigers with uncini arranged in a single row; last two uncinigers with neuropodia of abdominal type (pinnules). Uncini with one single row of five teeth above the rostral tooth (Figure 4E). From SGV (CH3), 16 thoracic segments with notopodial limbate capillary chaetae; those of $\mathrm{CH} 3$ very small. No intermediate segments. Abdomen with uncinigers provided with pinnules; rudimentary notopodia absent. Abdominal uncini similar in shape and arrangement to those of thorax (Figure 4F). Pygidium not seen.

\section{MG STAINING PATTERN}

Staining pattern similar to that of $M$. cristata. Anterior dorsal region heavily stained. Latero-ventral part of $\mathrm{CH} 3$ and $\mathrm{CH} 4$ white, slightly stained. Branchiae not stained. Membranous fold not stained. From $\mathrm{CH} 5$ to $\mathrm{CH} 16$, only lateral parts of segments stained. From $\mathrm{CH} 17$ to end of body dorsal part not stained. Ventral part of the body heavily stained from anterior end to $\mathrm{CH} 16$; $\mathrm{CH} 17$ gently stained, $\mathrm{CH} 18$ and whole abdominal region not stained.

\section{REMARKS}

Our specimens agree well with the detailed description provided by Fauvel (1936) who also discusses the affinities and differences of this species with similar species such as Melinna palmata Grube, 1870 and Melinnopsis arctica (Annenkova,1931), both East Atlantic species, and Melinnopsis monocera (Augener, 1906) from the Antilles. Day (1967) reproduced a shortened translation into English from the original French description of Fauvel (1936).

\section{DISTRIBUTION}

The species has been recorded only in the Mediterranean Sea-Morocco, at $224 \mathrm{~m}$ depth (Fauvel, 1936); Adriatic Sea (Katzmann, 1983, as M. cf. monoceroides, at $60 \mathrm{~m}$ depth), Aegean Sea (Arvanitidis, 2000), Italy (Castelli et al., 2008) and Egypt (Abd-Elnaby, 2009)-and the Atlantic (Day, 1967) in shallow waters (1-99 m depth). This is the northernmost record of the species. 
Subfamily AM P HA RE TINA E Malmgren, 1866

GenuS A M PHICTEIS Grube, 1850

Amphicteis indet.

\section{MATERIAL EXAMINED}

MNCN 16.01/15236 (DI13, 1 specimen).

\section{OCCURRENCE}

Capbreton Canyon (Bay of Biscay), 1040 m depth.

\section{DESCRIPTION}

One small and incomplete specimen $4.0 \mathrm{~mm}$ long, $0.5 \mathrm{~mm}$ wide. Prostomium U-shaped, with two longitudinal ridges on middle lobe and a pair of transversal nuchal slits (Amphicteis-type). Buccal tentacles not seen. Four pairs of very long and thin branchiae arranged in two well separated groups. Tip of longest branchia reaching thoracic $\mathrm{CH} 14$. Long and thin paleae, evenly tapered in a fine tip; around 15 per fascicle. Posterior to paleae, 17 thoracic chaetigerous segments with notopodia with limbate capillary notochaetae and last 14 with uncinigerous tori. Only two abdominal uncinigers with pinnules. No intermediate uncinigers.

\section{REMARKS}

Although the specimen is very small and incomplete, following Jirkov (2011) and Parapar et al. (2011) the combination of absence of intermediate uncinigers (genus character), and presence of evenly tapered paleae, point to a group of three species: $A$. gunneri (Sars, 1835), $A$. sundevalli Malmgren, 1866 and A. wesenbergae Parapar, Helgason, Jirkov \& Moreira,2011 (see key to Arctic and Boreal species of Amphicteis in Parapar et al., 2011). Amphicteis sundevalli is a high Arctic species and $A$. wesenbergae has long dorsal cirrus in the abdominal neuropodia. These facts clearly point to $A$. gunneri, a species already reported in the area (see below). Parapar et al. (2011) give a detailed SEM study of different characters of the species from Icelandic material, providing relevant information on some other diagnostic characters of the genusAmphicteis, namely the clavate papilla present in thoracic notopodia, the shape of the prostomium, thoracic and abdominal uncini and nephridial pori.

\section{DISTRIBUTION}

Rallo et al. (1993) report $A$. gunneri in the Capbreton Canyon. Due to actual problems in the delineation of $A$. gunneri, Parapar et al. (2011) propose a restricted distribution for this taxon from Arctic and North Atlantic European waters with a southern boundary probably located in the English Channel.

Amphicteis midas (Gosse, 1855)

(Figure 5)

Crassostoma midas Gosse, 1855: 310-313, figs 7-12, pl. 8. 
Amphicteis midas Hartley, 1985: 309-311, figs 1-2, tab. 1; Holthe, 1986a (in part): 56-57, fig. 21, map 20; Hartmann-Schröder, 1996: 495-496, fig. 241.

\section{MATERIAL EXAMINED}

MNCN 16.01/15233 (DI21, 22 specimens); POL427 (DI37, 2); POL428 (CM22, 36) and MNCN 16.01/15234 (KF50, 1).

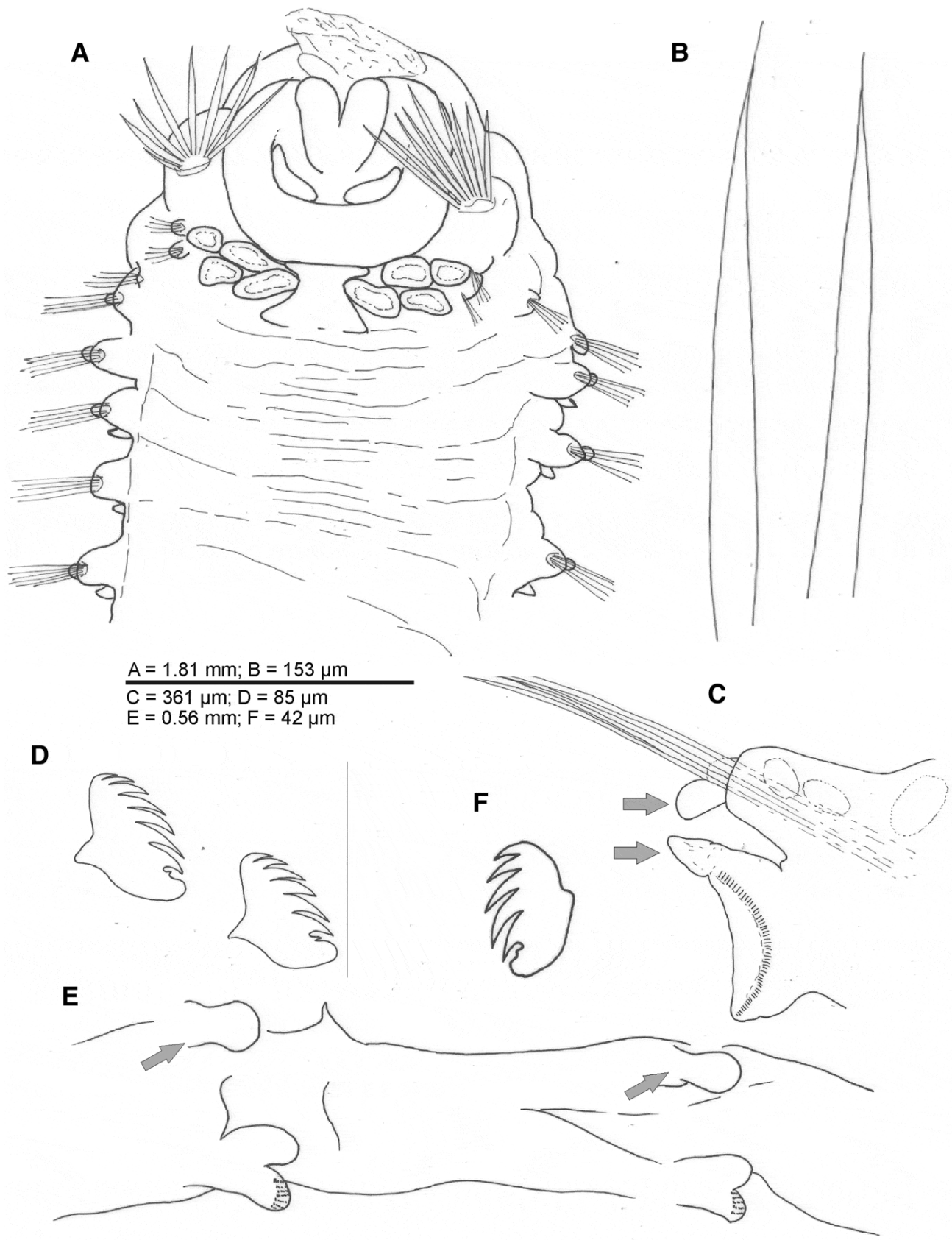

Fig. 5. Amphicteis midas: (A) anterior end, dorsal view; (B) two paleae; (C) thoracic chaetiger; showing rounded ventral cirrus on notopodia and triangular dorsal cirrus on neuropodia (arrows); (D) thoracic uncini, lateral view; (E) abdominal chaetigers, lateral view showing papilla-shaped rudimentary notopodia (arrow); (F) abdominal uncinus, lateral view. 


\section{OCCURRENCE}

Capbreton Canyon (Bay of Biscay), 508-1000 m depth.

\section{DESCRIPTION}

Complete specimen $27.5 \mathrm{~mm}$ long, $3 \mathrm{~mm}$ wide. Body long, wider anteriorly, and tapering posteriorly towards pygidium. Prostomium Amphicteis-type (Figure 5A). Paleae and 17 thoracic chaetigers with notopodial limbate capillary chaetae; last 14 with uncinigerous tori. SGI and SGII fused, produced into lower ventral lip. Four pairs of branchiae arranged in two well-separated groups; the four branchiae of each group arranged in two rows of two pairs (one pair beside first thoracic notopodium, and the other one beside second thoracic notopodium). Tip of longest branchia reaching thoracic $\mathrm{CH} 8$. SGIl with long paleae, abruptly tapering in a fine tip; 7-10 per fascicle (Figure 5A, B). Posterior to paleae, 17 thoracic chaetigerous segments with notopodia provided with limbate capillary notochaetae. Thoracic notopodia with ventral rounded cirrus (Figure $5 \mathrm{C}$ ). Fourteen thoracic neuropodia with a triangular cirrus in dorsal part of neuropodium (Figure 5C). Thoracic uncini in a single vertical row, each one with 5-6 teeth above rostral tooth (Figure 5D). No intermediate uncinigers. Fifteen abdominal uncinigers with papilla-shaped rudimentary notopodia (Figure $5 \mathrm{E}$ ). Neuropodial pinnules provided with rounded dorsal cirrus and a single row of uncini (Figure 5E). Abdominal uncini similar to those of thorax (Figure 5F). Pygidium with a pair of long, slender, filiform anal cirri.

\section{MG STAINING PATTERN}

Anterior region heavily stained. Interbranchial area heavily stained as well as two small areas each one situated behind basal part of each inner branchia of second row. Branchiae not stained. Notopodia of thoracic region heavily stained. Rest of thoracic dorsal region less stained but with a characteristic pattern of very fine transversal segmental rows; this pattern extending dorsally to pygidium. Rudimentary notopodia of abdominal region heavily stained. Thoracic ventral region from anterior end to $\mathrm{CH} 7$ heavily and uniformly stained. From $\mathrm{CH} 8$ glandular ridge heavily stained, fading in following segments. In $\mathrm{CH} 15$ glandular ridge gently stained and from $\mathrm{CH} 16$ almost not stained. Edges of thoracic neuropodia markedly stained. In abdominal region, only mid-ventral groove and areas next to neuropodia stained, in a similar pattern to that of dorsal region. Anal cirri slightly stained at their base.

\section{REMARKS}

Our specimens agree well with main characters provided by Hartley (1985) in the redescription of $A$. midas: 5-10 paleae abruptly tapering and large area between branchial groups.

\section{DISTRIBUTION}

Hartley (1985) characterizes $A$. midas as a shallow water $(0-27 \mathrm{~m})$ species in the British Isles and suggests that it is present in the west coast of Sweden and the Mediterranean Sea. Our findings confirm the presence of this species in the deep continental slope of the Bay of Biscay. 
(Figure 6)

Amphicteis wesenbergae Parapar et al., 2011: 1493-1494, figs 9-10.

\section{MATERIAL EXAMINED}

MNCN 16.01/15235 (CM22, 1 specimen).
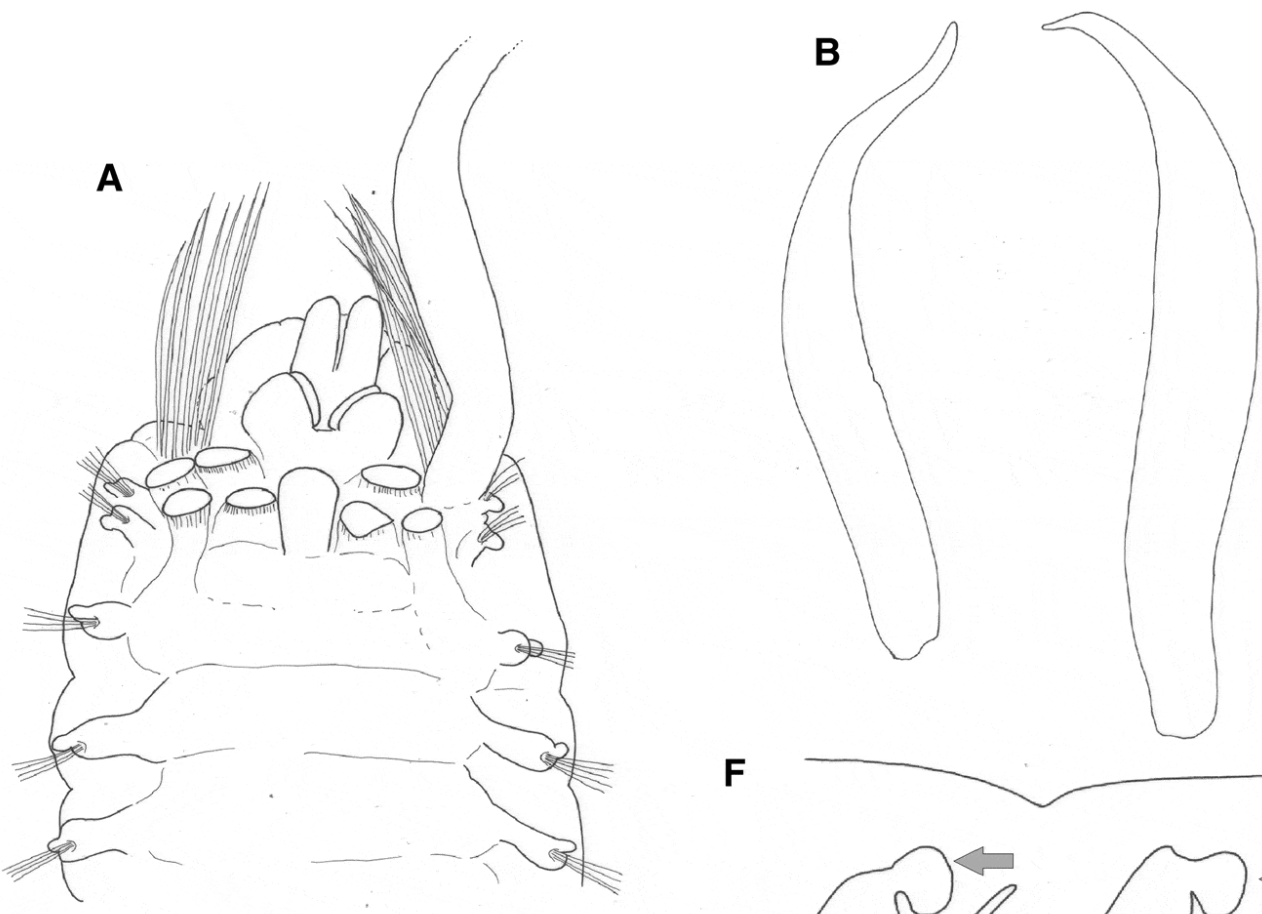

$\mathbf{F}$
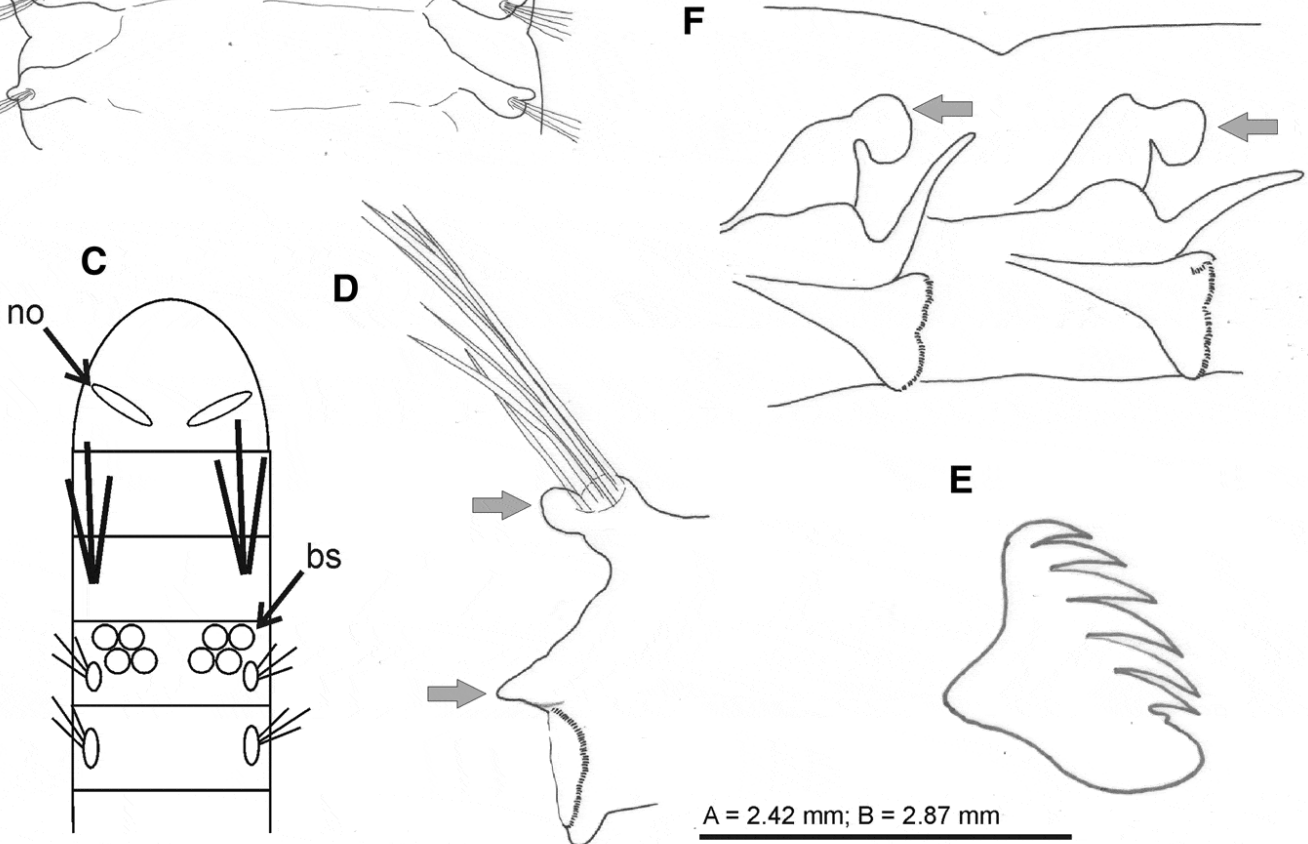

D
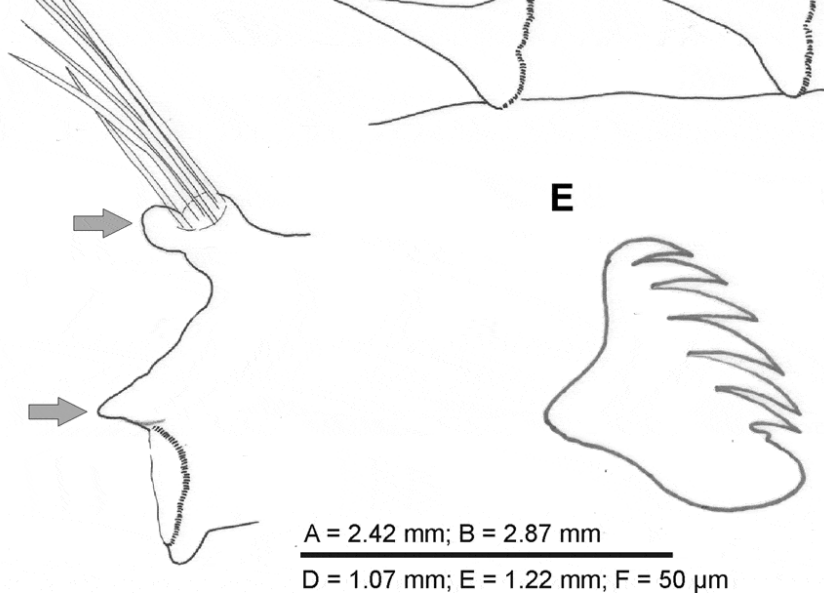

Fig. 6. Amphicteis aff. wesenbergae: (A) anterior end, dorsal view; (B) two branchiae; (C) schematic drawing showing arrangement of branchiae and chaetae in first thoracic segments; (D) thoracic chaetiger showing rounded ventral cirrus on notopodia and triangular dorsal cirrus on neuropodia (arrows); (E) thoracic uncinus, lateral view; (F) two abdominal uncinigers; showing papilla-shaped rudimentary notopodia (arrows). Abbreviations: bs = branchial scars; no $=$ nuchal organs. 


\section{ADDITIONAL COMPARATIVE MATERIAL}

Type material of Amphicteis wesenbergae. Holotype. Zoologisk Museum: ZMUC-POL-1871. 'Ingolf' Expedition Station 117 at east Norwegian Sea $\left(69^{\circ} 13^{\prime} \mathrm{N} 08^{\circ} 23^{\prime} \mathrm{W}\right), 1889 \mathrm{~m}$ depth.

Icelandic Museum of Natural History. IMNH 24087 (BIOICE Station 2776, 15 paratypes).

\section{OCCURRENCE}

Capbreton Canyon (Bay of Biscay), 624-652 m depth.

\section{DESCRIPTION}

One incomplete specimen, $27 \mathrm{~mm}$ long, $2.9 \mathrm{~mm}$ wide for 31 chaetigers. Body long, wide anteriorly, tapering posteriorly. Paleae and 17 thoracic chaetigers with notopodial limbate capillary chaetae; 14 thoracic uncinigers. ProstomiumAmphicteis-type (Figure 6A). Four pairs of branchiae arranged in two well separated groups. Four branchiae of each group arranged in two rows of two pairs, posteriormost pair slightly shifted dorsally (Figure 6A). Branchiae long, curled, flattened; progressively increasing width from base to middle part and then decreasing rapidly to its distal end in a fine tip (Figure 6B). SGI and SGIl fused, produced into lower ventral lip. SGIl provided with long and slender paleae, progressively tapering to fine tip; 9-10 per fascicle (Figure 6A, C). First notopodia reduced, gradually increasing in size to $\mathrm{CH}$. Thoracic notopodia cylindrical with small, rounded ventral cirrus (Figure 6D). Fourteen thoracic uncinigers with triangular dorsal cirrus on torus (Figure 6D). Thoracic uncini with a single vertical row of 5-6 teeth above rostral tooth (Figure 6E). No intermediate segments. At least 14 abdominal uncinigers with rudimentary papilla-shaped notopodia (Figure 6F). Abdominal pinnules with long and cirriform dorsal cirrus (Figure 6F). Abdominal uncini similar in shape to those of thoracic region. Pygidium not seen.

\section{MG STAINING PATTERN}

Anterior body region and interbranchial area heavily stained. Basal part of branchiae not stained. Notopodia of thoracic region heavily stained. Rest of thoracic region more gently stained in its dorsal part but with very fine transversal segmental rows arranged in a characteristic pattern, extending dorsally to end of body. Ventral region of thorax to $\mathrm{CH} 10$ heavily and uniformly stained being the glandular area progressively less stained from $\mathrm{CH} 11$ to $\mathrm{CH} 16$ in which staining almost disappearing. Edges of thoracic neuropodia markedly stained. In abdominal region, only mid-ventral groove and areas next to neuropodia stained, in similar pattern to dorsal region.

\section{REMARKS}

Even though the specimen is incomplete and poorly preserved, it is still possible to recognize the two main characteristics proposed by Parapar et al. (2011) for $A$. wesenbergae: slender, progressively tapered paleae and abdominal uncinigers provided with a long and cirriform dorsal cirrus. However, the flattened branchiae present in this specimen are different from those described by Parapar et al. (2011) as 'long and tapering' for this species. Species identification is tentative until more specimens are found in the area. 


\section{DISTRIBUTION}

South-western deep slope of Iceland (Parapar et al., 2011). This is the first report of the species after the original description.

Genus A NOBOTHRUS Levinsen, 1884

Anobothrus aff. gracilis (Malmgren, 1866)

(Figure 7)

Ampharete gracilis Malmgren, 1866: 365, pl. 26, fig. 75 .

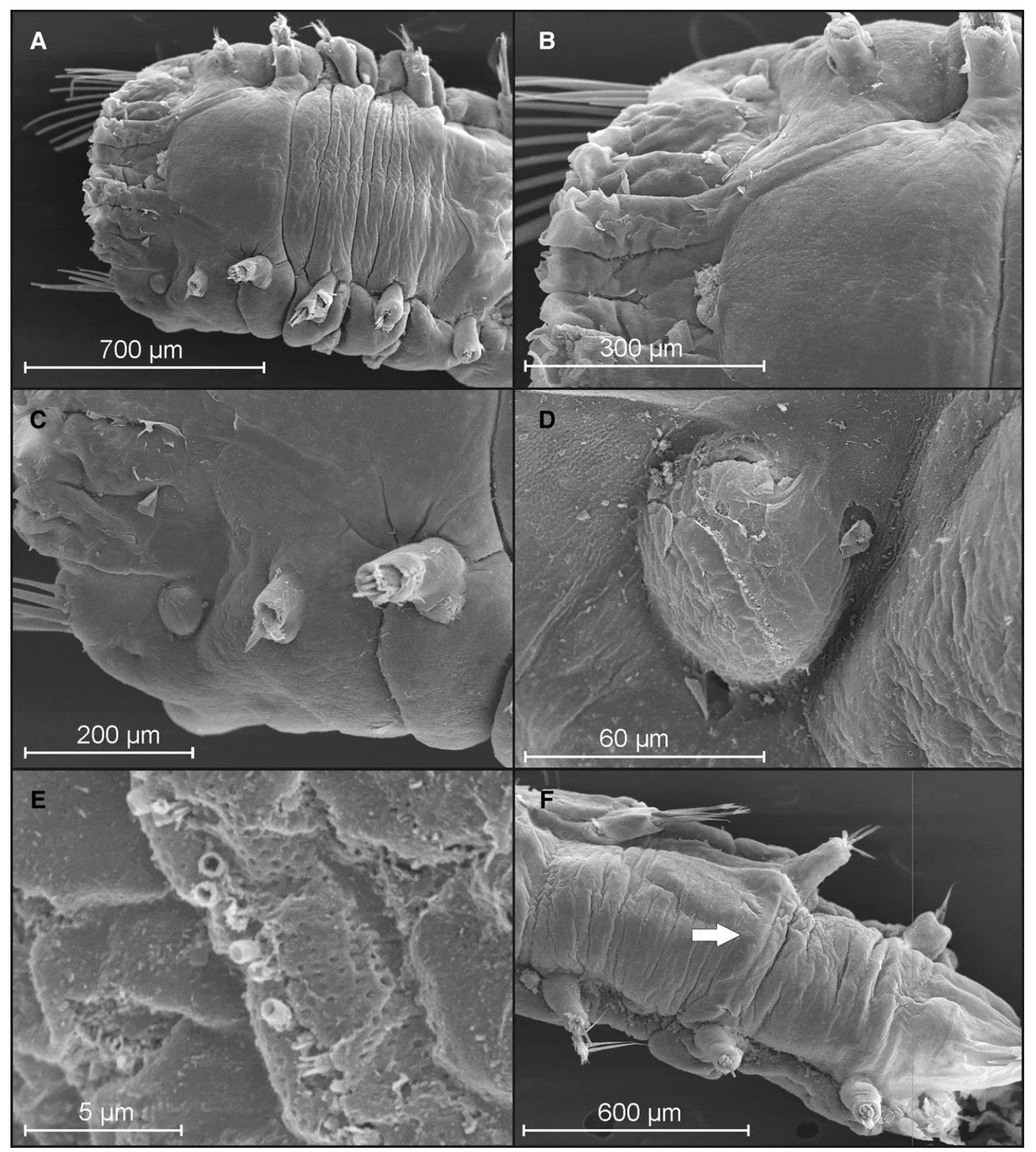

Fig. 7. Anobothrus aff. gracilis: (A) anterior end in dorsal view; (B) branchial cirrophores; (C) first three thoracic chaetigers; (D) first reduced chaetiger; $(E)$ detail of first thoracic chaetae; $(F)$ last three thoracic notopodia. Arrow showing dorsal transverse ridge at thoracic $\mathrm{CH} 11$. 
Anobothrus gracilis: Fauvel, 1927: 229-230, fig. 80 I-p; Holthe, 1986a: 50-51, fig. 18, map 17; Hartmann-Schröder, 1996: 497-498, fig. 242; Jirkov, 2001: 475-476 with textfig.; Jirkov, 2008: 122-124, figs 7,8 .

\section{MATERIAL EXAMINED}

MNCN 16.01/15237 (CM22, 1 specimen); JP personal collection (CM22, 1 in SEM stub).

\section{OCCURRENCE}

Capbreton Canyon (Bay of Biscay), 624-652 m depth.

\section{DESCRIPTION}

Two specimens; both without abdominal region. Longer one with oocytes in body cavity, broken at first abdominal segment; smaller one broken at thoracic $\mathrm{CH} 13$.

Prostomium U-shaped, with middle lobe delimited by incision, without glandular ridges (Ampharetetype); buccal tentacles and eyespots not seen. Paleae much longer than most developed notochaetae, gradually tapering towards distal end and $\sim 14$ in number. Four pairs of deciduous branchiae, only basal part (branchiophores) remaining. First three branchiophores of each side forming a straight transversal line (no gap between innermost branchiophores of each group) and defining a high fold; fourth situated behind and between two innermost branchiophores of each side (Figure 7A, B). Fifteen thoracic chaetigers provided with notopodia with capillary chaetae; first notopodia very small (Figure $7 \mathrm{C}-\mathrm{E}$ ), located laterally of outermost branchiophore of each side. Twelve thoracic uncinigers. A transversal pigmented band is present anterior to the third thoracic unciniger. Eleventh thoracic notopodia slightly elevated, but not transformed, connected by a low dermal transversal ridge (Figure 7F). Thoracic uncini with two vertical rows of six teeth above rostral tooth. Only first abdominal unciniger is observed in the more complete specimen, which is of thoracic type. Pygidium not seen.

\section{MG STAINING PATTERN}

Anterior body region heavily stained. Basal part of branchiae (branchiophores) not stained. Dorsal part of thoracic region (including transversal ridge) slightly stained; ventral thoracic region heavily and uniformly stained to $\mathrm{CH} 9$, then in a striped pattern.

The stain allows seeing the connection between the fourth branchiophore and the second thoracic notopodium, as previously described by Jirkov (2008).

\section{REMARKS}

Jirkov (2011) states that the genus Anobothrus, as other genera in Ampharetidae, has first two abdominal neuropodia of thoracic type (tori instead of pinnules), representing the intermediate uncinigers' of Imajima et al. (2012). 
Following the key to species of Anobothrus provided by Jirkov (2008), the lack in our specimens of most part of abdominal segments makes that they can be identified both as $A$. gracilis (13 abdominal segments), as well as Anobothrus mironovi Jirkov, 2008 and Anobothrus glandularis (HartmannSchröder, 1965) (both with 12). The geographic distribution of $A$. glandularis (south-east Pacific and Antarctica) and $A$. mironovi (North and south-east Pacific) (see Jirkov, 2008) makes very unlikely to correspond to such species, being more likely to be $A$. gracilis which is a species previously reported in waters near Capbreton (see below). The lack of a complete abdomen makes species identification tentative until more specimens are found in the area.

\section{DISTRIBUTION}

Anobothrus gracilis is a widely distributed species in Arctic and North Pacific waters at shelf and slope depths (Jirkov,2008). Rallo et al. (1993) report $A$. gracilis from the Capbreton Canyon which represented the first finding of the species in the Iberian Peninsula and the southernmost record of the species in the Atlantic Ocean.

Genus E CLY SIPPE Eliason, 1955

Eclysippe vanelli (Fauvel, 1936)

(Figures 8-10)

Lysippe vanelli Fauvel, 1936: 96-98, fig. 13.

Eclysippe vanelli Eliason, 1955: 10-14, fig. 3; Holthe, 1986a: 64-65, fig. 25, map 24; Kirkegaard, 1982: 257; Hartmann-Schröder, 1996: 498.

\section{MATERIAL EXAMINED}

MNCN 16.01/15238 (DI31, 3 specimens), POL429 (DI33, 35) and JP personal collection (DI33, 1 in SEM stub).

\section{ADDITIONAL COMPARATIVE MATERIAL}

Icelandic Museum of Natural History. Several specimens of Eclysippe vanelli from BIOICE samples 2311 and 2459.

\section{OCCURRENCE}

Capbreton Canyon (Bay of Biscay), 495-505 m depth.

\section{DESCRIPTION}

All specimens incomplete. Body elongate, wider in thoracic region. Prostomium triangular, with rounded end (Figures $8 \mathrm{~A}, 9 \mathrm{~A}-\mathrm{C}$ ). Eyes not seen. Ventral buccal lip formed by seven longitudinal folds, lateral two wider (Figure 9B). SGIl provided with conspicuous paleae, longer than thoracic notochaetae and pointed forwards (Figures 9A-C, 10A). SGIII provided with two groups of three branchiae arranged in transverse row; both groups separated by a narrow space (Figures $8 \mathrm{~A}, \mathrm{~B}, 9 \mathrm{~A}, 10 \mathrm{~A}$ ). Branchiae connected by a high 
membrane reaching the paleae (Figure 9A, B). Fifteen thoracic chaetigers with notopodia provided with limbate capillary chaetae starting on SGIII (Figures 8C, D, 10B); the posterior 12 also with neuropodia with uncini. First two thoracic chaetigers slightly shorter than following; last four clearly longer than the preceding ones (Figure 8A). Papilla visible in dorsal part of thoracic notopodia under the SEM (Figure $10 \mathrm{C}$ ). Thoracic uncini with two vertical rows of $4-5$ teeth each above rostral tooth (Figures $8 \mathrm{E}, 10 \mathrm{D}$ ). First two abdominal neuropodia of thoracic type ('intermediate uncinigers'); following neuropodia with typical abdominal pinnules, abdominal uncini similar to thoracic ones (Figure 8F). Pygidium and tube not seen.

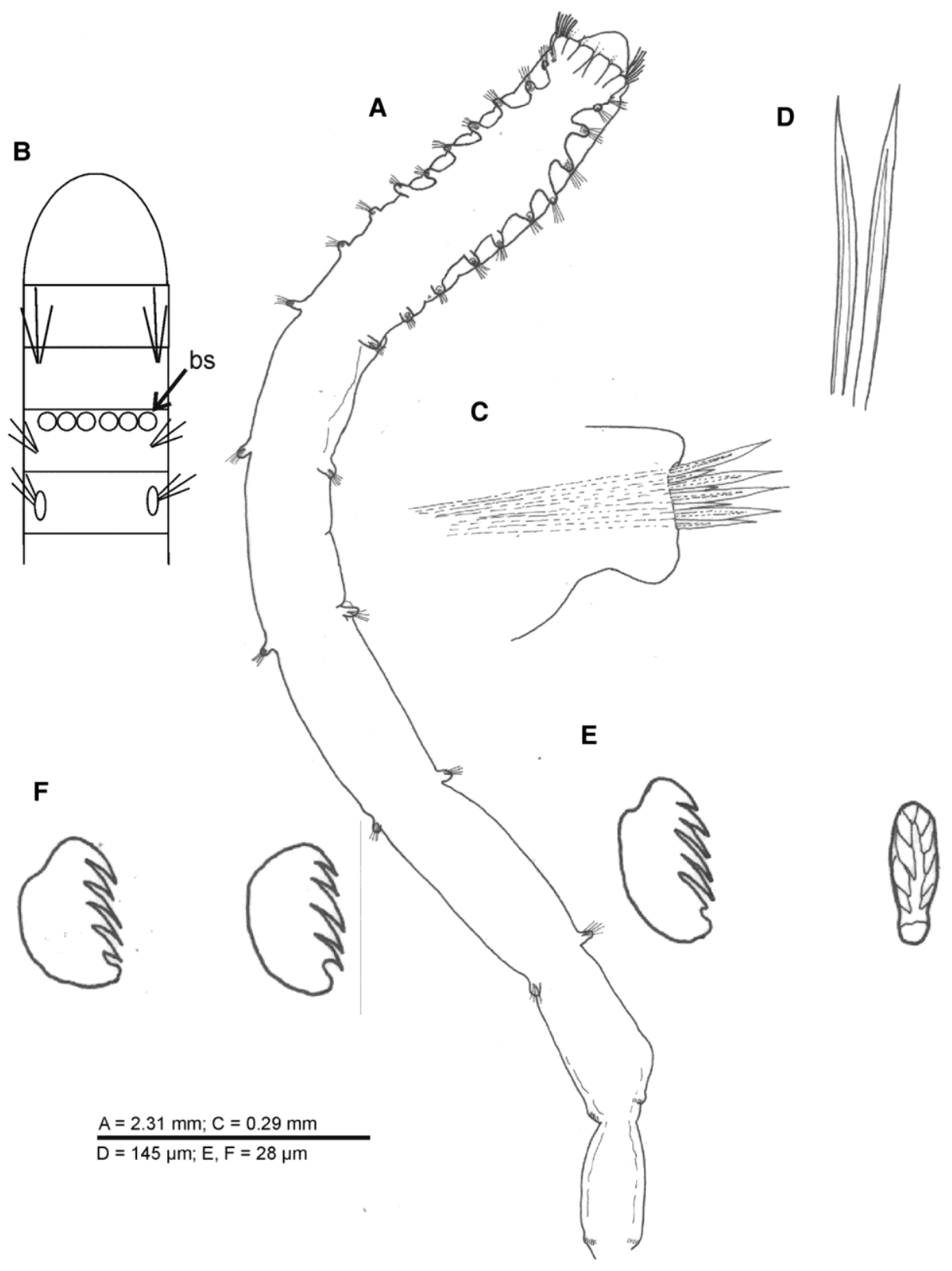

Fig. 8. Eclysippe vanelli: (A) semi-complete specimen, dorsal view; (B) schematic drawing showing arrangement of branchiae and chaetae in first thoracic segments; (C) first thoracic notopodium; (D) thoracic chaetae; (E) thoracic uncini, lateral and frontal view; (F) abdominal uncini, lateral view. Abbreviations: bs, branchial scars. 

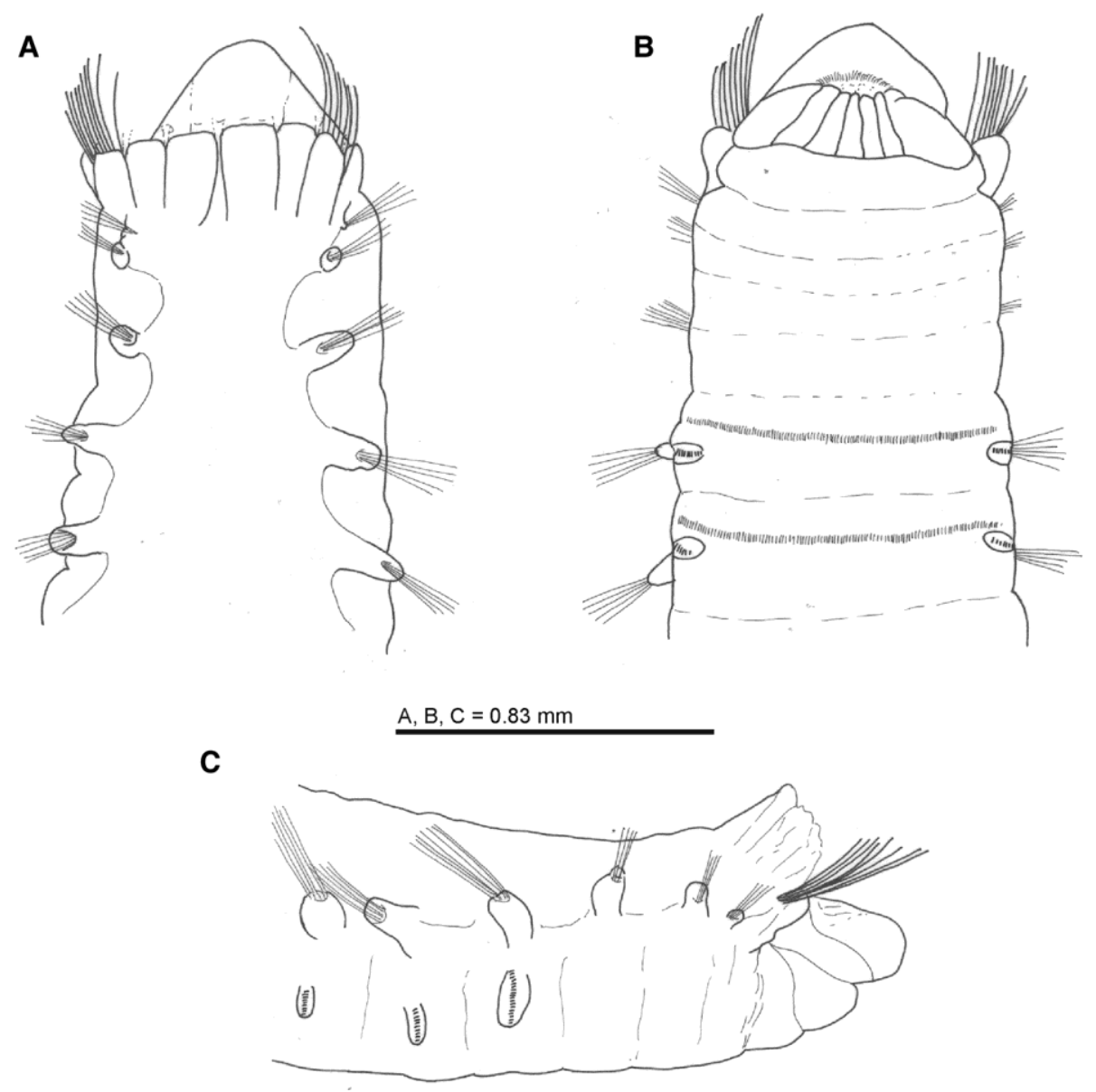

Fig. 9. Eclysippe vanelli: anterior end in dorsal $(A)$, ventral $(B)$ and lateral $(C)$ view.

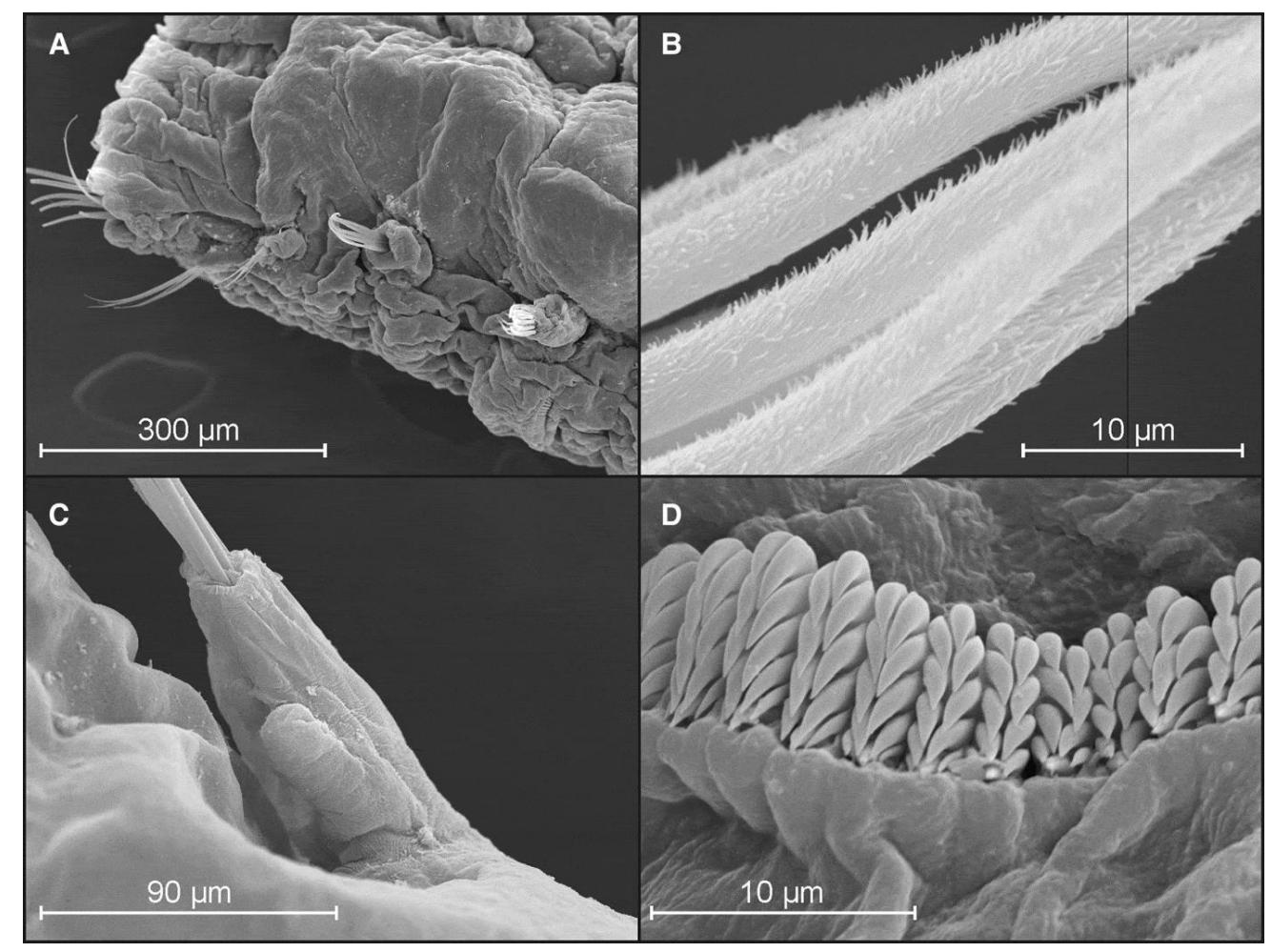

Fig. 10. Eclysippe vanelli: (A) anterior end, in dorso-lateral view; (B) detail of thoracic notochaetae; (C) thoracic notopodia 13; (D) thoracic uncini in frontal view. 


\section{MG STAINING PATTERN}

Anterior region heavily stained, both dorsally and ventrally. Branchiophores not stained. Dorsally, from paleal segment to $\mathrm{CH} 11$, only parapodia stained, mid-dorsal region not stained. Ventral region to $\mathrm{CH} 11$ heavily stained. From $\mathrm{CH} 12$, both dorsal and ventral regions not stained.

\section{REMARKS}

Our specimens agree with descriptions and drawings provided by Eliason (1955), Holthe (1986a) and Jirkov (2001) for E. vanelli. Therefore we do not follow Hansson (1998) who proposed that the Arctic and the North Sea material reported asE. vanelli should be Eclysippe eliasoni (Day, 1973), a species described by Day (1973) from the Beaufort Sea.

\section{DISTRIBUTION}

East Atlantic Ocean from the Barents Sea to the Great Meteor Bank and Guinea (Holthe, 1986a; Jirkov, 2001). The species was previously reported from the Iberian Peninsula including the Capbreton area by Martinez et al. (2007) as Eclysipe vanelli.

Genus GL Y PHANOSTOMUM Levinsen, 1884

Glyphanostomum moreirai sp. nov.

(Figures 11-13)

\section{TYPE MATERIAL EXAMINED}

POL430 (DI26, 2 paratypes); MNCN 16.01/15239 (KF42, holotype); MNCN 16.01/15240 (KF42, 2 paratypes); JP personal collection (DI13, 1 in SEM stub); JP personal collection (DI37, 1 in SEM stub); JP personal collection (DI66, 1 in SEM stub).

\section{ADDITIONAL COMPARATIVE MATERIAL}

Icelandic Museum of Natural History. Several specimens of Glyphanostomum pallescens (Théel, 1879) from BIOICE samples 2642 and 2591.

\section{OCCURRENCE}

Capbreton Canyon (Bay of Biscay), 508-1040 m depth.

\section{DESCRIPTION OF HOLOTYPE}

Specimen complete, $10.44 \mathrm{~mm}$ long and maximum width of $0.78 \mathrm{~mm}$. Body long and slender; anteriorly enlarged and tapering posteriorly. Prostomium scoop-shaped (Figures $11 \mathrm{~A} ; 12 \mathrm{~A}$ ), dorsally and laterally surrounding large mouth opening, fused with first two segments forming lower lip (Figure 11B). Eye-spots not seen. Numerous smooth buccal tentacles (Figure 11D). SGI and SGIl each provided with a pair of dorsolateral conical lappets. Lateral expansion of SGI large, foliose and distally pointed; lateral expansion of SGIl shorter, low and distally rounded (Figures 11A, C, D; 12A). SGIl without paleae, ventrally forming transversal fold (Figure 11B-D). Three pairs of cirriform, distally pointed, slender 
branchiae located in SGIII (CH1). Left and right group of branchiae widely separated (Figure 11A, C). First two branchiae of each group in a transverse row; third pair located behind. (Figures 11C, 13). Chaetae starting on SGIII. Fourteen thoracic chaetigers provided with notopodial limbate capillary chaetae organized in two rows; an anterior row of fine chaetae (Figure 12B, C) and a posterior row of larger ones (Figure 12C, D). First two thoracic chaetigers slightly reduced. From thoracic $\mathrm{CH} 4$ (SGVI), 11 thoracic chaetigers provided also with low tori. Each torus with 10-12 uncini arranged in a single row. Thoracic uncini with two vertical rows of two teeth each above rostral tooth and two uppermost teeth (Figure 11E). Thoracic chaetigers ventrally provided with a transversal glandular ridge conspicuous from $\mathrm{CH} 3-4$. Abdomen narrower than thorax and approximately half of its length. Eleven abdominal chaetigers provided with neuropodial pinnules; no rudimentary notopodia. First abdominal segment ventrally provided with a transversal glandular ridge as in thorax; absent in remaining abdominal
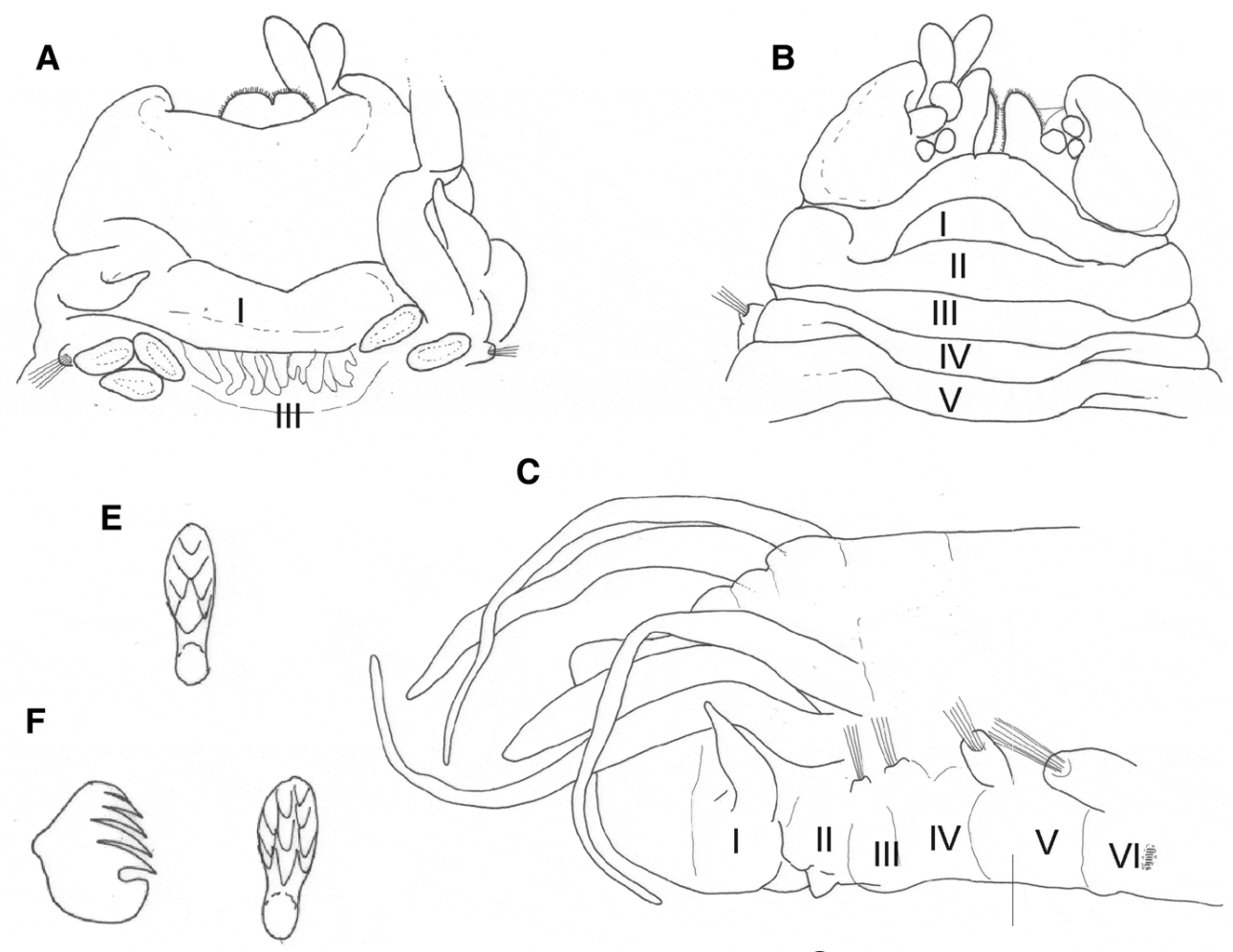

D

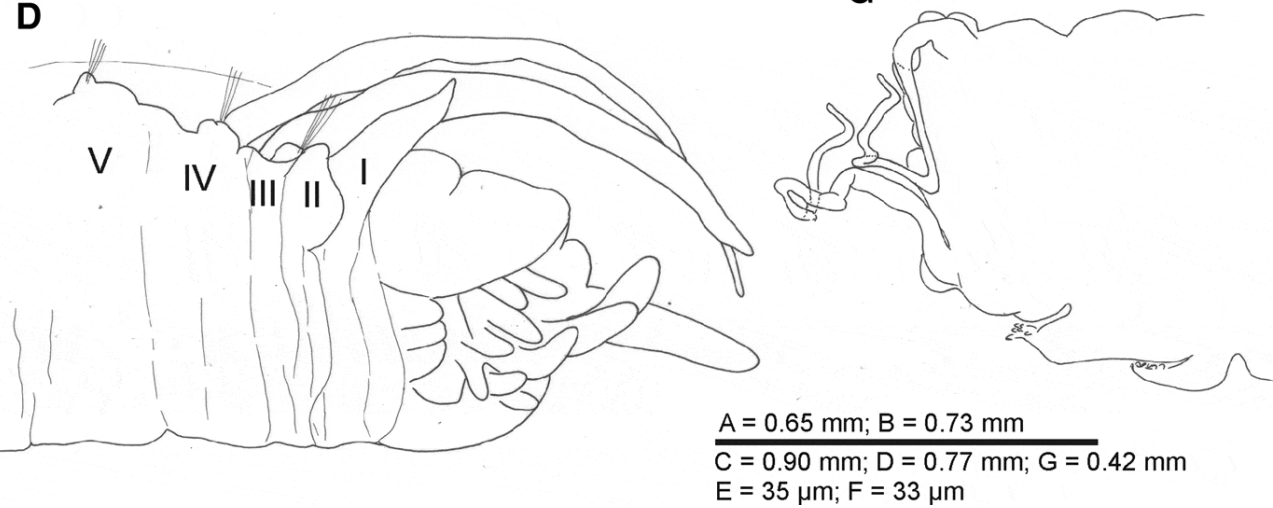

Fig. 11. Glyphanostomum moreirai sp. nov.: (A) anterior end in dorsal view; (B) anterior end in ventral view; $(C, D)$ anterior end in lateral view; $(E)$ thoracic uncinus in frontal view; $(F)$ abdominal uncini in lateral and frontal view; $(G)$ posterior end in ventral view. Segments indicated by Roman numerals. 
segments. Abdominal uncinigerous pinnules with $\sim 10$ uncini arranged in a single row. Abdominal uncini with two vertical rows of four teeth each and a median row of two teeth above rostral tooth (Figure 11F). Pygidium provided with a pair of long, slender, filiform lateral anal cirri (Figure 11G). Tube unknown.

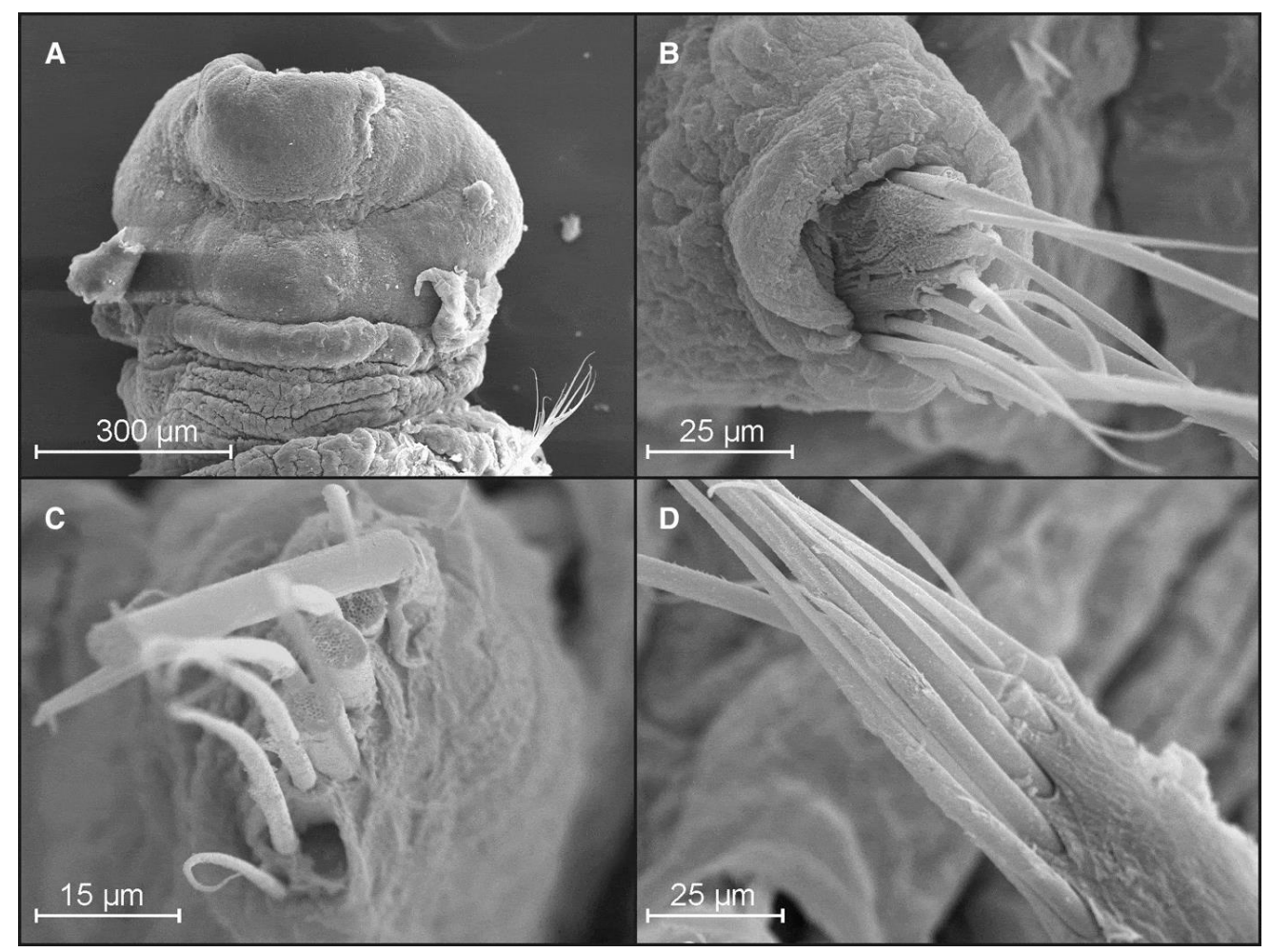

Fig. 12. Glyphanostomum moreirai sp. nov.: (A) anterior end, dorsal view; (B) chaetiger 6 , anterior view; (C) chaetiger 7; (D) chaetiger 8, posterior view.

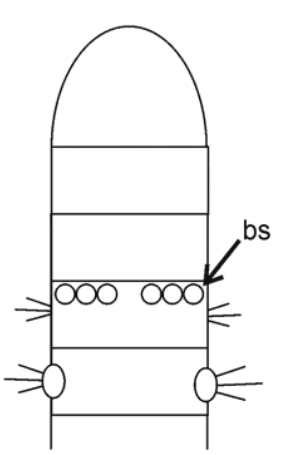

G. pallescens

(Théel, 1879)

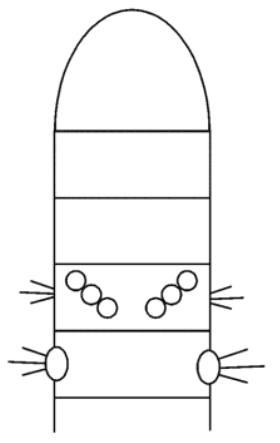

G. scotiarum Hartman, 1978

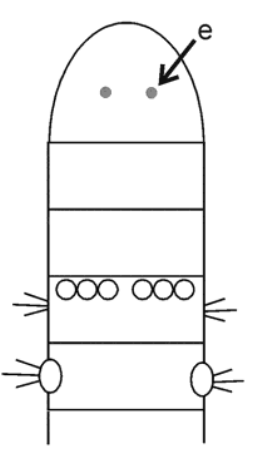

G. abyssale Day, 1967

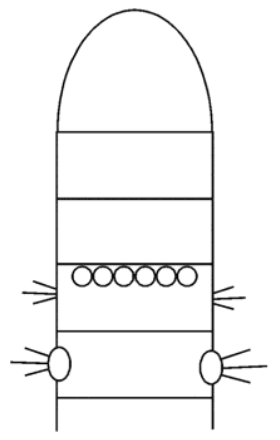

G. holthei

Reuscher et al., 2009
Fig. 13. Schematic drawings showing arrangement of branchiae and chaetae in first thoracic segments of all known species of genusGlyphanostomum. Abbreviations: bs, branchial scars; e, eyes; le-I, lateral expansion of segment I; le-II, lateral expansion of segment II.

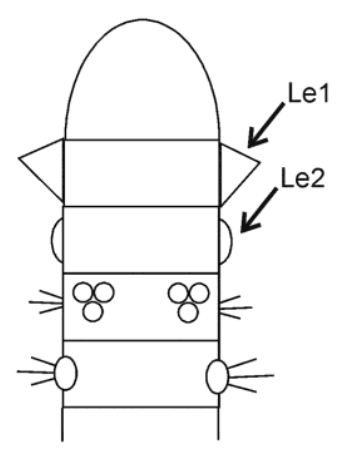

G. moreirai spec. nov. 


\section{MG STAINING PATTERN}

Anterior dorsal region heavily stained. Dorsal part of $\mathrm{CH} 1$ and interbranchial region heavily stained. Branchiae and buccal tentacles not stained. Rest of dorsal region to pygidium gently stained with very fine striped pattern. Thoracic notopodia more heavily stained. Anterior ventral region to $\mathrm{CH} 4$ heavily and uniformly stained. From $\mathrm{CH} 5$ to last thoracic chaetiger, a wide transversal band heavily stained in each chaetiger giving to the thoracic ventral region a characteristic striped aspect. Abdominal ventral region heavily stained. Pygidium and anal cirri not stained.

\section{REMARKS}

Following Reuscher et al. (2009) in the subfamily Ampharetinae only two genera have three pairs of branchiae and 11 thoracic uncinigers: Ampharana Hartman, 1967 and Glyphanostomum Levinsen, 1884. Since the branchiae are not segmentally arranged, as in Ampharana, but grouped in one segment (SGIII, $\mathrm{CH} 1$ ), our specimens are being described in the genus Glyphanostomum; the genus is also characterized by lacking chaetae in SGII, three pairs of branchiae, and thorax provided with 14 chaetigerous segments, 11 of them uncinigers.

Four species of Glyphanostomum have been described: G. pallescens (Théel, 1879) (widely distributed in North Atlantic Ocean, Arctic and Pacific Ocean to California), G. abyssale Day, 1967 (South Africa), G. scotiarum Hartman, 1978(Antarctica) and G. holthei Reuscher, Fiege \& Wehe, 2009 (Aleutian Trench, North East Pacific).

Nevertheless, there are several significant differences between the new species and all known Glyphanostomum. For instance, the prostomium is more similar to that of the genera Ampharete or Amage, instead of being simple as expected in the genus; on the other hand, the presence of lateral expansions in SGI and SGII also clearly distinguish the new species from any other Glyphanostomum species. Moreover, the number of abdominal chaetigers and shape of uncini are different. Number of abdominal uncinigers is 11 in the new species, much lower than in any Glyphanostomum species (30 in G. pallescens, 32 in G. abyssalis and 33 in G. scotiarum); all type material of $G$. holthei are incomplete specimens but with at least 11 abdominal chaetigers. The shape of the uncini in G. moreirai spec. nov., while very different from that of G. abyssalis (see Day, 1967, fig. 35.5. k, I), G. pallescens (see Ushakov, 1965, fig. 138 k; Jirkov, 2011, fig. 5) and G. scotiarum (see Hartman, 1978, fig. 34e), is similar to that of G. holthei (Reuscher et al., 2009, fig. 5d, e).

Reuscher et al. (2009) used the arrangement of the gills as the main character to differentiate species in this genus. Based on this arrangement, three groups of species can be now defined (Figure 13): branchiae arranged in a transverse row (G. pallescens, G. abyssale, G. holthel), in an oblique row (G. scotiarum), or grouped (G. moreirai sp. nov.).

Jirkov (2011) reviewed the taxonomic value of some characters traditionally used in ampharetid taxonomy, denying the value of certain meristic and qualitative characters (number of segments and branchiae, number of TU, presence/absence of paleae, and so on.) in the delimitation of genera and proposing alternative characters (shape of prostomium, branchial arrangement, types and position of 
neuropodia along the body) in a new key. Following Jirkov's new generic classification, the erection of a new genus for our specimens seems justified. We believe, however, that this would bring more confusion to a family with an already high number of genera described, many of them monotypical (Holthe, 2002). Only in the frame of a worldwide revision of the family, including careful rethinking of diagnoses and delimitation of genera, this might be justified.

\section{ETYMOLOGY}

This species is dedicated to Dr Juan Moreira (Universidad Autónoma de Madrid, Spain) for his help and friendship.

\section{KEY TO SPECIES OF GENUS GLYPHANOSTOMUM LEVINSEN, 1884}

The following key is based on that given by Reuscher et al. (2009) in which the arrangement of the gills was used as the distinguishing feature between species.

1. Median gap between left and right group of branchiae absent G. holthei

- Median gap between groups of branchiae present …................................................. 2

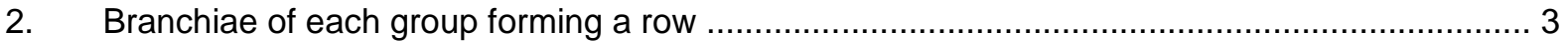

- Branchiae of each group not forming a row G. moreirai sp. nov.

3. Branchiae of each group in oblique row G. scotiarum - Branchiae in straight row across dorsum 4

4. Narrow median gap between groups of branchiae; eyes present G. abyssale

- Wide median gap between groups of branchiae; eyes absent G. pallescens

Genus TAN SE I M A R U A N A Imajima, Reuscher \& Fiege, 2013

Tanseimaruana vestis (Hartman, 1965)

(Figure 14)

Tanseimaruana vestis Imajima et al., 2013: 158.

Amphicteis vestis Hartman, 1965: 215-216, fig. 46; Parapar et al., 2011: 1487-1493, figs 6-8. MATERIAL EXAMINED

MNCN 16.01/15241 (DI26, 10 specimens). 
Icelandic Institute of Natural History. Several specimens of Tanseimaruana vestis from BIOICE sample 2983.

\section{OCCURRENCE}

Capbreton Canyon (Bay of Biscay), 984-1040 m depth.
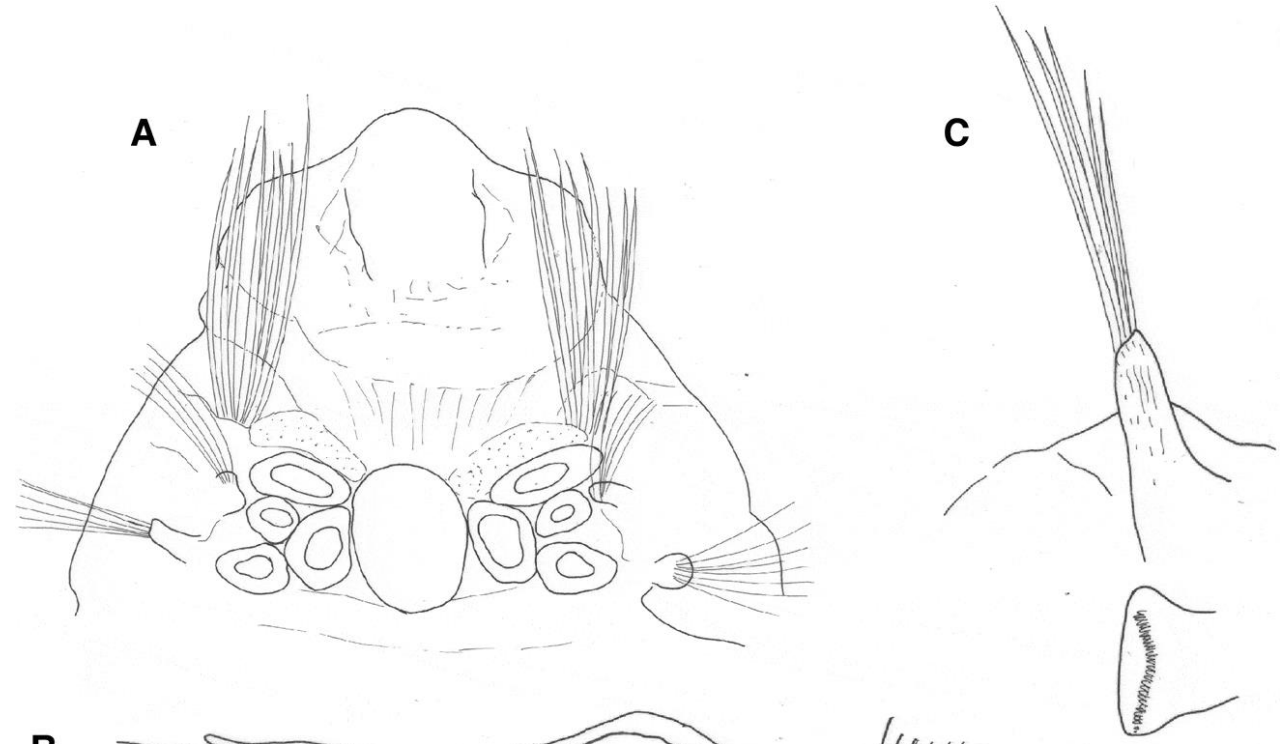

B
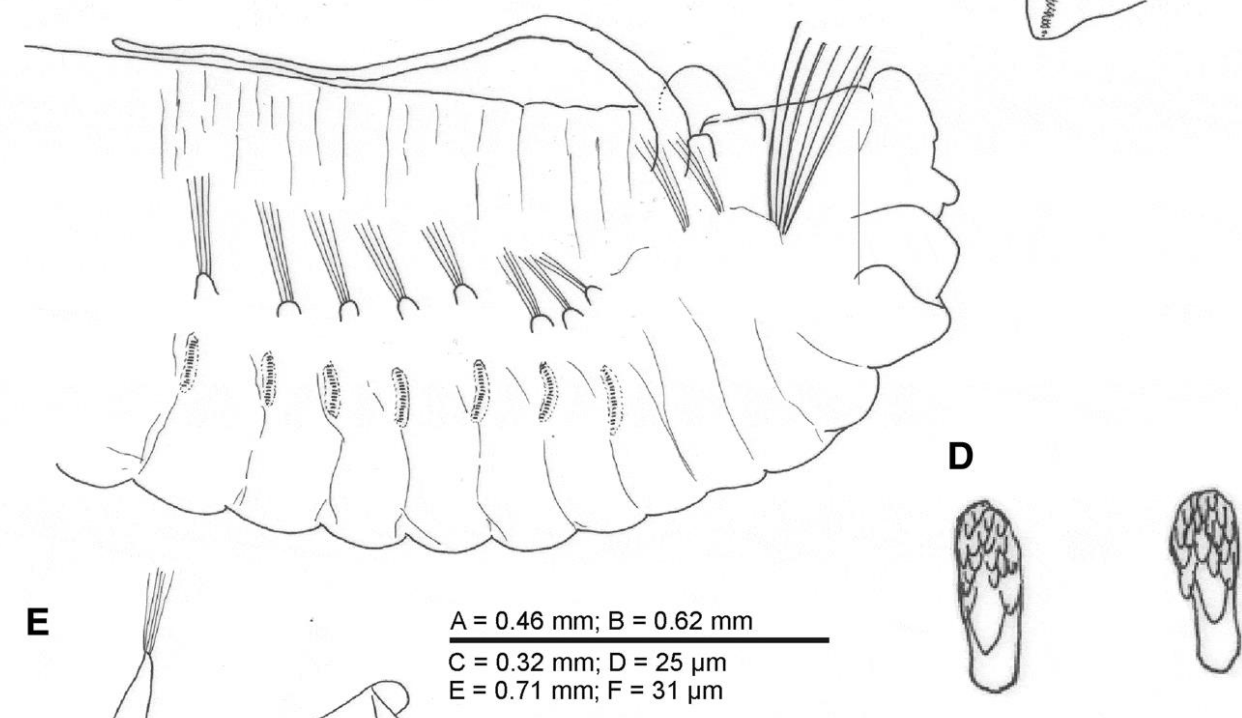

$\mathbf{F}$
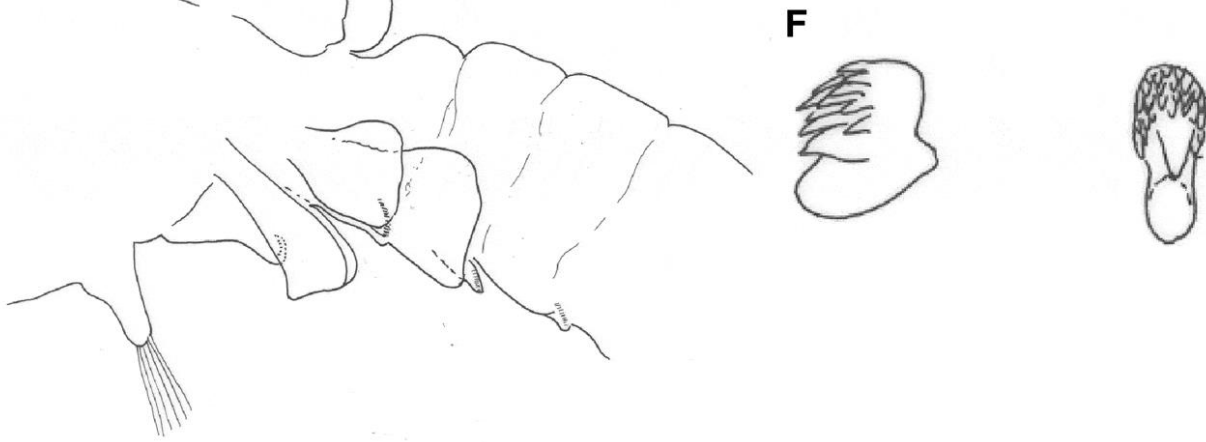

Fig. 14. Tanseimaruana vestis: (A) anterior end, dorsal view; (B) anterior end, lateral view; (C) thoracic chaetiger; (D) thoracic uncini, frontal view; $(E)$ thorax-abdomen transition, lateral view; $(F)$ abdominal uncini, frontal and lateral view. 


\section{DESCRIPTION}

Length $3.5-5.5 \mathrm{~mm}$, maximum width $0.6-0.9 \mathrm{~mm}$. Body wide anteriorly, tapering posteriorly. Prostomium roughly pentagonal (Figure 14A), with a pair of deep lateral grooves. Four pairs of long and slender branchiae arranged in two well separated groups; in each group scars of anteriormost and innermost branchiae larger than other two (Figure 14A). First pair of branchiae located behind paleae, second and third pairs beside first thoracic notopodium, and fourth pair beside second thoracic notopodium (Figure 14A). First pair of branchiae longer, reaching last thoracic chaetigers; three remaining pairs half of their length. Both groups of branchiae separated by an elevated rounded area (Figure 14A, B). Thorax with paleae and 17 thoracic chaetigers provided with notopodial limbate capillary chaetae. Paleae and two following thoracic notopodia more dorsally located than rest of notopodia (Figure 14B). Sixteen to 17 long and slender paleae per paleal fascicle, pointing forwards. Fourteen thoracic uncinigers; starting from thoracic $\mathrm{CH} 4$ (excluding paleae) and each torus provided with 30-40 uncini arranged in a single row (Figure 14C). Thoracic uncini with one large rostral tooth and a capitium of several transversal rows of small teeth (Figure 14D). Intermediate uncinigers absent. Thirteen abdominal uncinigers with pinnules. First abdominal unciniger with dermal bilobed folds (one specimen with dermal folds in first two abdominal chaetigers in one side; Figure 14E). Abdominal rudimentary notopodia absent; pinnules with 14-16 uncini arranged in a single row, similar in shape to those of thoracic region but smaller (Figure 14F). Pigidium with one pair of cirriform anal cirri. Some specimens with oocytes in body cavity.

\section{MG STAINING PATTERN}

Anterior dorsal region and interbranchial area heavily stained. Branchiae not stained. Rest of thoracic dorsal region slightly stained. Abdomen not stained. Anterior ventral region heavily stained to $\mathrm{CH} 11$, specially the glandular ridge, $\mathrm{CH} 12$ and $\mathrm{CH} 13$ less stained and fading in $\mathrm{CH} 14$. Thoracic parapodia slightly stained.

\section{REMARKS}

The most conspicuous character of $T$. vestis is the presence of a double fanlike neuropodial structure in the first abdominal chaetiger (Hartman, 1965; Parapar et al., 2011). All species of the genus Jugamphicteis Fauchald \& Hancock, 1981 (J. sibogae (Caullery, 1944), J. sargassoensis (Hartman \& Fauchald, 1971), J. paleata Fauchald \& Hancock, 1981 and J. galatheae Holthe, 2000), Ampharete vega Wirén, 1883 and $T$. vestis (Hartman, 1965) share a similar character. Nevertheless, T. vestis has bilobed foliose neuropodia in the first abdominal segment and not medially fused notopodial valve-like structures (Fauchald \& Hancock, 1981) or with the fan-like notopodial structure connected at middorsum (Holthe, 2000) which characterizes the genus Jugamphicteis. Moreover, T. vestis differs from genus Jugamphicteis by the absence of prostomial glandular ridges and the characteristic nuchal organs of this genus (see Holthe, 2000). Tanseimaruana vestisdiffers from $A$. vega in the number of thoracic chaetigers-14 in A. vega and 17 in T. vestis-in the shape of the expanded abdominal notopodialobate in $A$. vega and bilobed foliose in $T$. vestis-and in the presence of 2-3 abdominal segments with rudimentary notopodia in $A$. vega, absent in $T$. vestis. 
Our specimens agree with all the generic features of Tanseimaruana provided by Imajima et al. (2013) and characteristics of T. vestis provided by Hartman (1965) and recently by Parapar et al. (2011) (as Amphicteis): prostomium without glandular ridges or nuchal organs, number and arrangement of branchiae, paleal segment and 17 thoracic notopodia provided with limbate capillary chaetae and without cirri, 14 thoracic uncinigers, absence of abdominal notopodial rudiments and double fan-like notopodial structure in the first abdominal chaetiger.

\section{DISTRIBUTION}

Tanseimaruana vestis was originally described off New England (western Atlantic) by Hartman (1965) and recently reported in north-eastern Atlantic waters by Parapar et al. (2011). The north-east Pacific record by Kucheruk (1976) may correspond to the recently described Japanese species $T$. boninensis Imajima, Reuscher \& Fiege, 2013. Tanseimaruana vestis was also reported in Antarctica by Schüller and Ebbe (ANDEEP-SYSTCO preliminary resuls on-line), but it may correspond to a different species. This is the first report of the species in the Iberian Peninsula and the southernmost from the eastern Atlantic Ocean.

\section{Ampharetinae indet.}

(Figures 15, 16)

\section{MATERIAL EXAMINED}

JP personal collection (KF50, 1 specimen in SEM stub).

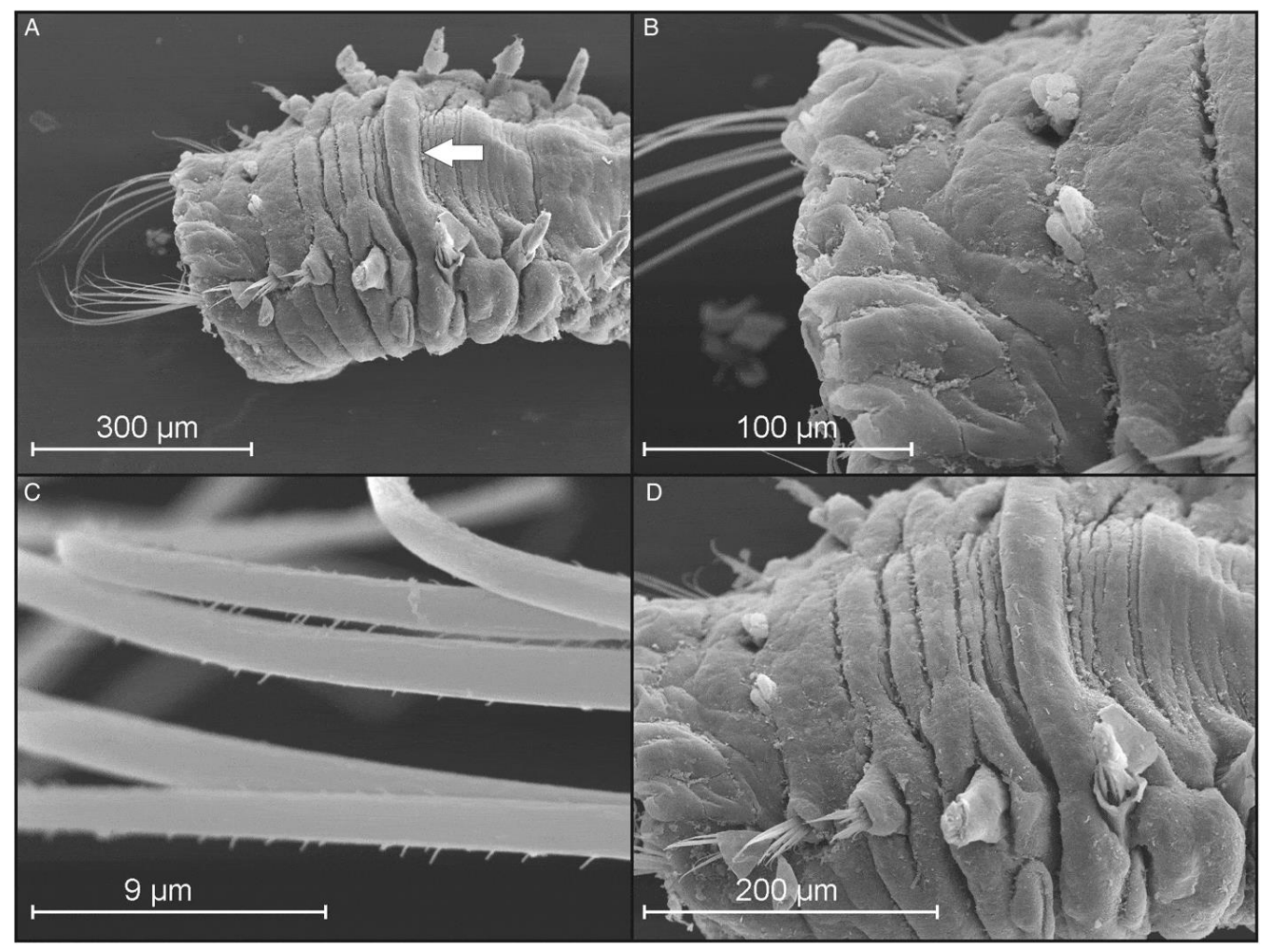

Fig. 15. Ampharetinae indet.: (A) anterior end in dorsal view; (B) branchial cirrophores; (C) paleae; (D) first five thoracic chaetigers. Arrow showing dorsal transverse ridge at thoracic $\mathrm{CH} 5$. 


\section{OCCURRENCE}

Capbreton Canyon (Bay of Biscay), 1000 m depth.

\section{DESCRIPTION}

One specimen, incomplete, broken at thoracic $\mathrm{CH} 9$. Prostomium Ampharete-type; buccal tentacles not seen. Eyespots absent. Three pairs of deciduous branchiae, only branchiophores remaining and forming a straight transversal row (no gap between innermost branchiophores of each group) forming a high fold. Paleae much longer than the most developed notochaetae, but of similar width and $\sim 14$ in number (Figures 15A, B); paleae provided with hispid surface (Figure 15C). First notopodia small, provided with only 1-4 hispid notochaetae (Figure 16B), and located posterior to the outermost branchiophores of each side. Second thoracic notopodia larger than first but smaller than following. From fourth thoracic chaetiger, uncinigerous tori also present (Figures 15D, 16A). A transversal glandular ridge across the dorsum present before second thoracic unciniger (Figure 15A, D). Thoracic uncini almost hidden between neuropodial lobes (Figure 16C), with a capitium composed by one horizontal row of four large teeth above rostral tooth and several uppermost smaller teeth (Figure 16D).

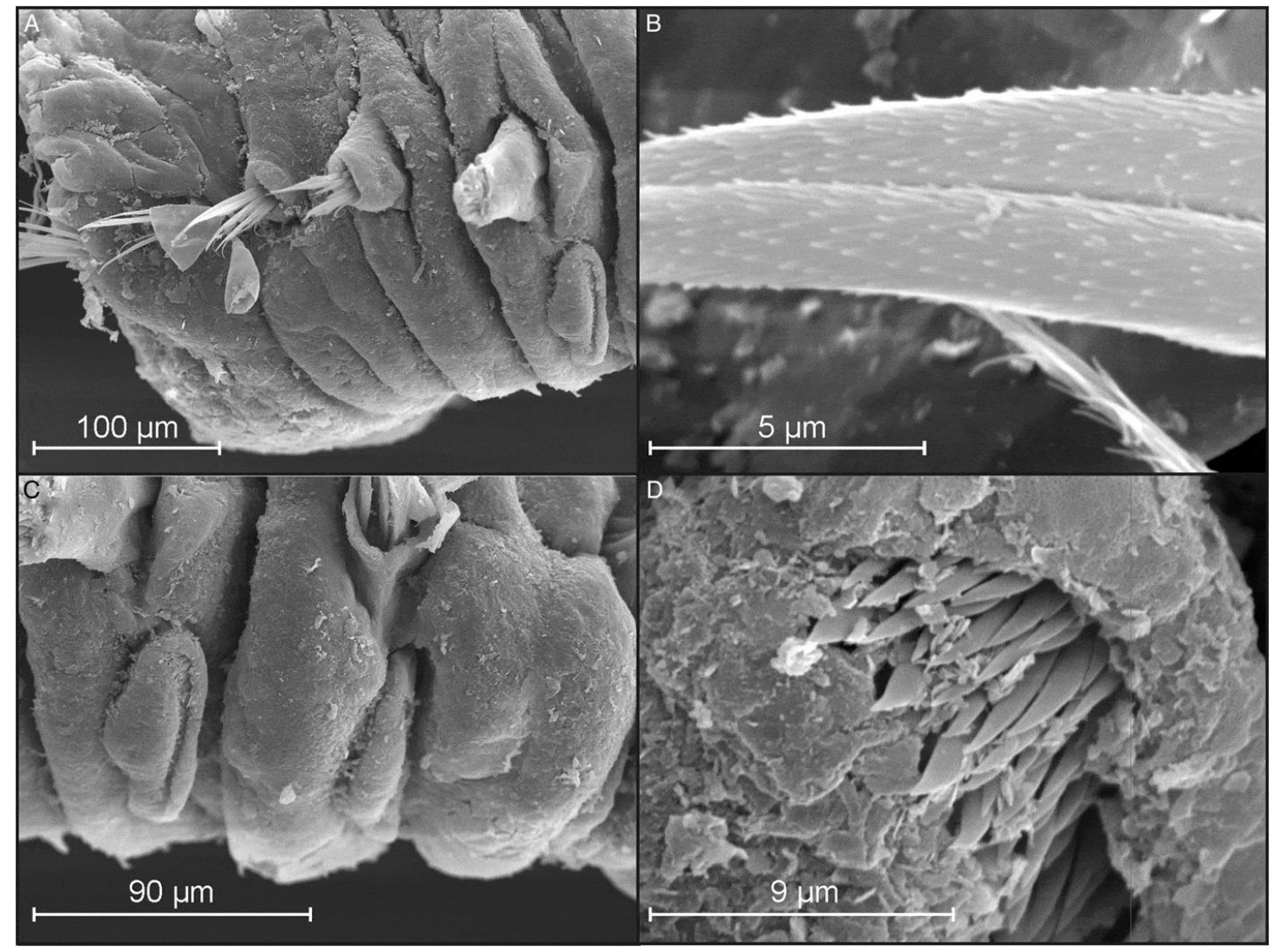

Fig. 16. Ampharetinae indet.: (A) anterior end in lateral view; (B) notochaetae; (C) first three biramous thoracic chaetigers; (D) thoracic uncini in frontal view. 


\section{MG STAINING PATTERN}

Anterior body region heavily stained. Branchiophores not stained. Notopodia and neuropodia of thoracic region not stained. Dorsal part of thoracic region (including transversal ridge) not stained; ventral thoracic region heavily stained in a striped pattern.

\section{REMARKS}

Despite only one incomplete specimen is available, general appearance is highly consistent with the original description of Anobothrus laubieri (Desbruyères, 1978) (see descriptions in Holthe, 1986a; Jirkov, 2001, 2008; and table 6 in Reuscher et al., 2009). Nevertheless, the specimen lacks the posterior part of the thorax that has a dorsal ridge at eighth thoracic unciniger, which is a highly characteristic feature of the genus. Anyway, more specimens are needed to confirm the presence in Capbreton of this deep-water (>2000 m depth) Arctic species.

\section{ACKNOWLEDGEMENTS}

Thanks are due to Départment de Géologie et Océanographie (DGO, Talence) for the loan of the Flusha box-corer, to Laboratoire de Biologie des Invertébrés Marins (BIMM-MNHN, Paris) for the loan of the sieving equipment, to the French Comité Interrégional Manche Atlantique (CIRMAT-CNRS) for logistical support and the loan of an epibenthic dredge, to the crew of the RV 'Côte d'Aquitaine' for their assistance at sea, and to A. Urzelai, I. Esteban and I. Zabala (INSUB, San Sebastian) for their helpful contribution to the sorting of samples. This Franco-Spanish Co-operative Research Programme was partly supported by the French CIRMAT-CNRS (Capbreton cruises 1988 and 1989). We wish to thank G. Gudmundsson (IMNH) and G.V. Helgason (University of Iceland), and D. Eibye-Jacobsen and M.T. Tøttrup (ZMUC) for making available specimens from selected species. Special thanks are due to J.C. Sorbe, director of the CAPBRETON research programme. A. Castro and C. Sueiro (SAIN, UDC) assisted with the preparation of specimens and the use of the SEM, Igor Jirkov (Moscow State University, Russia), Juan Moreira (Universidad Autónoma de Madrid, Spain) and E. Martínez-Ansemil (Universidade da Coruña, Spain) provided valuable comments on different aspects of the manuscript. Two anonymous referees are greatly acknowledged for their constructive comments on the manuscript.

\section{FINANCIAL SUPPORT}

This Franco-Spanish Co-operative Research Programme was partly supported by the French CIRMATCNRS (Capbreton cruises 1988 and 1989). 


\section{REFERENCES}

Abd-Elnaby F.A. (2009) Polychaete study in northeastern Mediterranean coast of Egypt. World Journal of Fish and Marine Sciences 1, 85-93.

Aguirrezabalaga F. and Carrera-Parra L. (2006) Lumbrineridae (Polychaeta) from the Capbreton Canyon (Bay of Biscay, NE Atlantic) with the description of two new species. Scientia Marina 70S3, 1725.

Aguirrezabalaga F. and Ceberio A. (2003) Dorvilleidae (Polychaeta) from the Capbreton Canyon (Bay of Biscay, N-E Atlantic) with the description of Pettiboneia sanmartinisp. nov. Cahiers de Biologie Marine 44, 41-48.

Aguirrezabalaga F. and Ceberio A. (2005a) Sphaerodoropsis amoureuxi and S. stellifer, two new species of Sphaerodoridae (Polychaeta) from the Capbreton Canyon (Bay of Biscay, NE Atlantic). Cahiers de Biologie Marine 46, 9-20.

Aguirrezabalaga F. and Ceberio A. (2005b) Spionidae (Annelida: Polychaeta) from the Capbreton Canyon (Bay of Biscay, NE Atlantic) with description of a new genus and three new species. Marine Biology Research 1, 267-280.

Aguirrezabalaga F. and Ceberio A. (2006) Flabelligena gascognensis sp. nov. (Polychaeta: Acrocirridae) a new species from the Capbreton Canyon (Bay of Biscay, NE Atlantic). Scientia Marina 70 S1, 141-147.

Aguirrezabalaga F. and Gil J.(2009) Paraonidae (Polychaeta) from the Capbreton Canyon (Bay of Biscay, NE Atlantic) with the description of eight new species. Scientia Marina 73, 631-666.

Aguirrezabalaga F., Ceberio A. and Fiege D.(2001) Octomagelona bizkaiensis (Polychaeta: Magelonidae) a new genus and species from the Capbreton Canyon (Bay of Biscay, north-east Atlantic). Journal of the Marine Biological Association of the United Kingdom 81, 221-224.

Aguirrezabalaga F., Ceberio A. and Paxton H. (2002) Onuphidae (Polychaeta) from the Capbreton Canyon (Bay of Biscay, NE Atlantic) with the description of Paradiopatra capbretonensis sp. nov. Steenstrupia 27, 19-28.

Aguirrezabalaga F. , San Martín G. , Petersen M.E. and Ceberio A. (1999) Presencia de Dysponetus gracilis Hartman, 1965 (Polychaeta, Chrysopetalidae) en las costas europeas, Golfo de Vizcaya. Boletín de la Real Sociedad Española de Historia Natural (Sección Biología) 95, 21-25.

Annenkova N.P. (1931) Zur Polychaetenfauna von Franz-Joseph Land (Melinnexis gen. nov. arctica sp. nov.). Zoologischer Anzeiger 95, 269-272.

Ariño A. (1987) Bibliografía Ibérica de Poliquetos. Base de datos y catálogo de especies. Publicaciones de Biología de la Universidad de Navarra, vol. 16. Navarra: Ediciones Universidad de Navarra, 143 pp.

Arvanitidis C. (2000) Polychaete fauna of the Aegean Sea: inventory and new information. Bulletin of Marine Science 66,73-96.

Augener H. (1906) Westindische Polychaeten. Bulletin of the Museum of Comparative Zoology 43, 9196.

Castelli A., Bianchi C.N., Cantone G. , Çinar M.E. , Gambi M.C. , Giangrande A. , Iraci Sareri G., Lanera P. , Licciano M. , Musco L., Sanfilippo R. and Simonini R. (2008) Annelida Polychaeta. Biologia Marina Mediterranea 15 (Suppl.), 323-373.

Caullery M. (1944) Polychètes sédentaires de I'Expedition du SIBOGA: Ariciidae, Spionidae, Chaetopteridae, Chloraemidae, Opheliidae, Oweniidae, Sabellariidae, Sternaspidae, Amphictenidae, Ampharetidae, Terebellidae. Siboga Expedition 24(2),1-204.

Chamberlin R.V. (1919) The Annelida Polychaeta. Memoirs of the Museum of Comparative Zoology 48, 1-514.

Day J.H. (1967) A Monograph of the Polychaeta of Southern Africa. Part. 2. Sedentaria. London: British Museum (Natural History), No. 656, pp. 459-878.

Day J.H. (1973) New Polychaeta from Beaufort, with a key to all species recorded from North Carolina. NOAA Technical Report NMFS CIRC no. 375, 140 pp. 
Desbruyères D. (1978) Melythasides laubierigen. et sp. nov. Ampharetidae (Annélides polychètes sédentaires) abyssal de la Mer de Norvège. Bulletin du Muséum National d'Histoire Naturelle Paris 353(514), 231-238.

Ehlers E. (1887) Reports on the Annelids. Reports on the results of dredging, under the Direction of L. F. Pourtalés, during the years 1868-1870, and of Alexander Agassiz, in the Gulf of Mexico (1877-78), and in the Caribbean Sea (1878-79), on the US coast survey steamer Blake, Lieut. Com. C.D. Sigsbee, USN, and Commander J.R. Bartlett, USN Commanding. Memoirs of the Museum of Comparative Zoology at Harvard College 15, 1-335.

Eliason A. (1955) Neue oder wenig bekannte Schwedische Ampharetiden (Polychaeta). Kungelige Vetenskaps och vitterhets-Samhällets i Göteborg Handlingar 6, 3-17.

Fauchald K. and Hancock D.R. (1981) Deep-water polychaetes from a transect off central Oregon. Allan Hancock Foundation Monographs 11, 1-73.

Fauvel P. (1927) Polychétes sédentaires. Faune de France 16, 1-494.

Fauvel P. (1936) Contribution a la faune des annélides polychètes du Maroc. Mémoires de la Société des Sciences Naturelles et Physiques du Maroc 43, 1-143.

Gosse P.H. (1855) Notes on some new or little known marine animals III. Annals and Magazine of Natural History 16,305-313.

Grube A.-E. (1850) Die Familien der Anneliden. Archiv für Naturgeschichte 16, 249-364.

Grube A.-E. (1870) Bemerkungen über die Amphicteneen und Amphareteen. Jahresbericht der Schlesischen Gesellschaft für Vaterländische Cultur 48, 68-84.

Hansson H.G. (1998) NEAT (North East Atlantic Taxa): south Scandinavian marine Annelida check-list. Available at:http://www.tmbl.gu.se/libdb/taxon/neat_pdf/NEAT*Annelida.pdf (accessed 8 October 2013).

Hartley J.P. (1985) The re-establishment of Amphicteis midas (Gosse, 1855) and redescription of the type material of $A$. gunneri (M. Sars, 1835) (Polychaeta: Ampharetidae). Sarsia 70, 309-316.

Hartman O. (1965) Deep-water benthic polychaetous annelids off New England to Bermuda and other North Atlantic areas. Occasional Papers of the Allan Hancock Foundation, 28, 1-378.

Hartman O. (1967) Polychaetous annelids collected by the USNS Eltanin and Staten Islands cruises, chiefly from Antarctic Seas. Allan Hancock Monographs in Marine Biology 2, 1-387.

Hartman O. (1978) Polychaeta from the Weddell Sea Quadrant, Antarctica. Biology of the Antarctic Seas VI. Antarctic Research Series 26, 125-223.

Hartman O. and Fauchald K. (1971) Deep-water benthic polychaetous annelids off New England to Bermuda and other North Atlantic areas. Part II. Allan Hancock Monographs in Marine Biology 6, 1-327.

Hilbig B. (2000) Chapter 8. Family Ampharetidae Malmgren, 1867. In J. Blake, B. Hilbig and P. Scott (eds) Taxonomic atlas of the benthic fauna of the Santa Maria Basin and the Western Santa Barbara Channel. Vol. 7. Santa Barbara, CA: Santa Barbara Museum of Natural History, pp. 169-230.

Holthe T. (1986a) Polychaeta Terebellomorpha. In Marine Invertebrates of Scandinavia. Vol. 7. Oslo: Universitetsforlaget, $191 \mathrm{pp}$.

Holthe T. (1986b) Evolution, systematics and distribution of the Polychaeta Terebellomorpha, with a catalogue of the taxa and a bibliography. Gunneria 55, 1-236.

Holthe T. (2000) Bathyal and abyssal Ampharetidae (Annelida: Polychaeta) (sedentary species II). Galathea Reports, 18,57-68.

Holthe T. (2002) One new genus and three new species of the Ampharetidae (Polychaeta: Terebellida) from the Bioshelf project. Phuket Marine Biological Center Special Publication 24, 345-351.

Imajima M., Reuscher M.G. and Fiege D. (2012) Ampharetidae (Annelida: Polychaeta) from Japan. Part I: the genusAmpharete Malmgren, 1866, along with a discussion of several taxonomic characters of the family and the introduction of a new identification tool. Zootaxa 3490, 75-88.

Imajima M., Reuscher M.G. and Fiege D. (2013) Ampharetidae (Annelida: Polychaeta) from Japan. Part II: genera with elevated and modified notopodia. Zootaxa 3647, 137-166.

Jirkov I.A. (2001) Polychaeta of the Arctic Ocean. Moscow: Yanus-K: Moskva. [In Russian.]

Jirkov I.A. (2008) Revision of Ampharetidae (Polychaeta) with modified thoracic notopodia. Invertebrate Zoology 5, 111-132. 
Jirkov I.A. (2011) Discussion of taxonomic characters and classification of Ampharetidae (Polychaeta). Italian Journal of Zoology 78, 78-94.

Katzmann W. (1983) Bemerkungen zur systematik, ökologie und tiergeographie der mitteladriatischen weichbodenpolychaeten. Annalen des Naturhistorisches Museums Wien, 84, 87-122.

Kirkegaard J.B. (1982) New records of abyssal benthic polychaetes from the Polar Sea. Steenstrupia 8, 253-260.

Levinsen G.M.R. (1884) Systematisk-geografisk Oversigt over de nordiske Annulata, Gephyrea, Chaetognathi og Balanoglossi. 2. Videnskabelige Meddelelser Dansk Naturhistorisk Forening 1883, 92350.

Lucas Y., San Martín G. and Parapar J. (2012) Two new species of Syllidae (Polychaeta) from DIVAArtabria I project (cruise 2002) to deep areas off Galicia (NW Spain). Zootaxa 3589, 77-88.

Mackie A.S.Y. and Pleijel F. (1995) A review of the Melinna cristata-species group (Polychaeta: Ampharetidae) in the northeastern Atlantic. Mitteilungen aus dem Hamburger Zoologischen Museum und Institut 92, 103-124.

Malmgren A.J. (1866) Nordiska Hafs-Annulater. Öfvers. K. Vetensk Akademie Stockholm Förhandlingar 22, 355-410.

Martínez J., Adarraga I. and Ruiz J.Ma . (2007) Tipificación de poblaciones bentónicas de los fondos blandos de la plataforma continental de Guipúzcoa (sureste del golfo de Vizcaya). Boletín del Instituto Español de Oceanografía 23,85-110.

Moreira J. and Parapar J. (2007) Sphaerodoridae (Annelida, Polychaeta) from the DIVA-ARTABRIA I project (2002 cruise) with description of a new species from the Ártabro Gulf (NW Iberian Peninsula). Cahiers de Biologie Marine 48, 373-379.

Nuñez J., Aguirrezabalaga F. and Ceberio A. (2000) Species of Nereididae from the Capbreton Canyon (Bay of Biscay, Northeast Atlantic). Bulletin of Marine Science 67, 25-37.

Parapar J. and Moreira J. (2009) Polychaeta of the 'DIVA-Artabria I' project (cruise 2002) in the continental shelf and upper slope off Galicia (NW Spain). Cahiers de Biologie Marine 50, 57-78.

Parapar J., Besteiro C. and Urgorri V. (1996) Inventario dos Poliquetos de Galicia (Annelida: Polychaeta). Cadernos da Área de Ciéncias Biolóxicas. Inventarios XVI. Publicacións do Seminário de Estudos Galegos, $178 \mathrm{pp}$.

Parapar J. , Helgason G.V. , Jirkov I. and Moreira J. (2011) Taxonomy and distribution of the genus Amphicteis (Polychaeta: Ampharetidae) collected by the Biolce project in Icelandic waters. Journal of Natural History 45, 1477-1499.

Parapar J., Helgason G.V., Jirkov I. and Moreira J. (2012) Polychaetes of the genus Ampharete (Polychaeta: Ampharetidae) collected in Icelandic waters during the BIOICE project. Helgoland Marine Research 66, 331-344.

Rallo A., García-Arberas L. and Isasi l. (1993) Fauna macrobéntica de los fondos del cañón de Capbretón: análisis faunístico de poliquetos, crustáceos y cnidarios y caracterización de puntos de muestreo según estos descriptores. Cahiers de Biologie Marine 35, 69-90.

Reuscher M., Fiege D. and Wehe T. (2009) Four new species of Ampharetidae (Annelida: Polychaeta) from Pacific hot vents and cold seeps, with a key and synoptic table of characters for all genera. Zootaxa 2191, 1-40.

Salazar-Vallejo S.I. and Hutchings P. (2012) A review of characters useful in delineating ampharetid genera (Polychaeta).Zootaxa 3402, 45-53.

San Martín G., Ceberio A. and Aguirrezabalaga F. (1996) Exogone species (Polychaeta: Syllidae: Exogoninae) from the Capbreton Canyon (Bay of Biscay, NE Atlantic). Cahiers de Biologie Marine 37, 249-258.

Sars M. (1835) Beskrivelser og lagttagleser over nogle maerkelige eller nye i Havet ved den Bergenske Kyst levende Dyr af Polypernes, Acephalernes, Radiaternes, Annelidernes og Molluskernes Classer, med en kort Oversigt ober de hidtil af Forfatteren sammesteds fundne Arter og deres Forekommen. Bergen, $80 \mathrm{pp}$.

Sars M. (1851) Beretning om en i Sommeren 1849 foretagen zoologisk Reise i Lofoten og Finnmarken. Nytt Magazin for Naturvidenskaberne 6, 121-211. 
Schüller M. (2008) New polychaete species collected during the expedition ANDEEP I, II, and III to the deep Atlantic sector of the Southern Ocean in the austral summers 2002 and 2005- Ampharetidae, Opheliidae, and Scalibregmatidae. Zootaxa1705, 51-68.

Schüller M. and Hutchings P. (2010) New insights in the taxonomy of Trichobranchidae (Polychaeta) with description of a new Terebellides species from Australia. Zootaxa 2395, 1-16.

Théel H.J. (1879) Les annélides polychètes des mers de la Nouvelle-Zemble. Kongl. Vetenskaps Academiens Handlingar 16,1-75.

Ushakov P.V. (1965) Polychaeta of the far eastern seas of the USSR. Jerusalem: Israel Program for Scientific Translations, Jerusalem, $419 \mathrm{pp}$. 